\title{
How to humiliate and shame: A reporter's guide to the power of the mugshot.
}

Paul Lashmar, Brunel University

\section{Introduction}

The 'mugshot' - the police or prison photograph - is a ubiquitous and instantly recognisable form, appearing in the media, on the internet, on book covers, law enforcement noticeboards and used ironically on tee-shirts and tea mugs. The mugshot is simple and specific early sub genus of the photographic portrait, again of the wider taxon, the portrait. As a journalist covering crime in the national news media for thirty years I have used mugshots to illustrate stories for their explicit and specific content without giving much thought to their implicit connotations as images. It was only after becoming an academic that the idea came to examine the layers of meaning that mugshots convey. The catalyst was the release in 2012 of a historic set of photographs, indeed very early mugshots, of Dorchester prisoners from the 1870 s until the end of the $19^{\text {th }}$ century. These rediscovered images were released to the news media and run at length, for instance, in the Daily Mail. ${ }^{\mathrm{i}}$
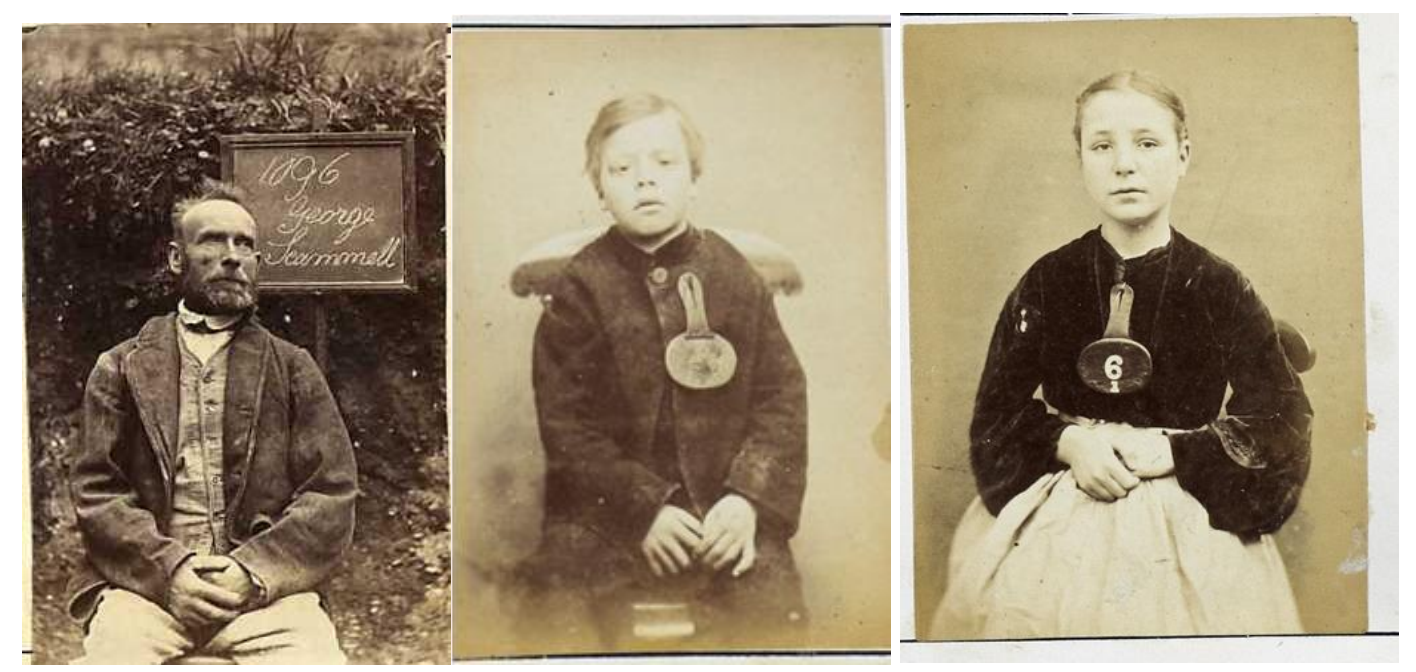

1. George Scammell tried 4 July 1883 found guilty of obtaining money by false pretences.

2. The Juvenile Offender: Luther Gosney 10 years old. In 1876 he was committed to Dorset County Gaol charged with stealing two tin horns valued at $8 \mathrm{~d}$.

3. Juvenile Offender: Priscilla Penfold. 12 years old. She was charged with stealing a cloak valued at $25 \mathrm{~s}$. (Images by permission of the Dorset History Centre)

I was struck both by how much the style of the photographs changed over 25 years with a semi-formal portrait style becomes austere and functional. 


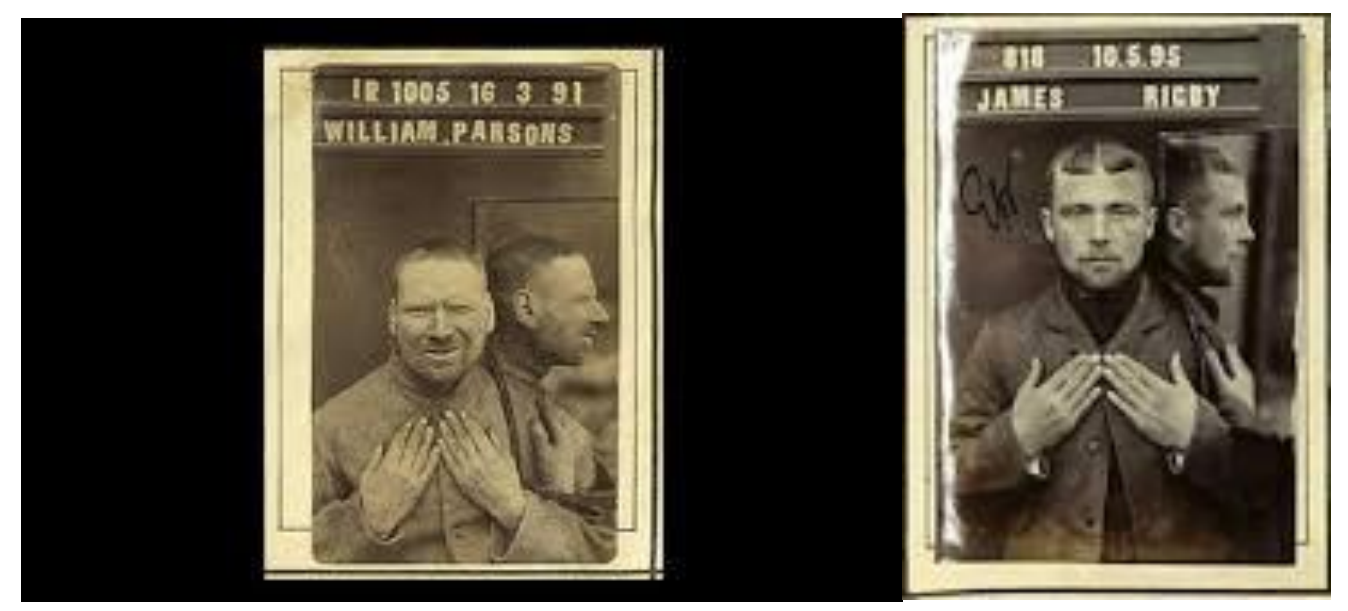

From 1890s Dorchester Prison album. (Images by permission of the Dorset History Centre)

Moreover I observed the way the meaning of these photographs has changed since these were taken; demonstrating how much the signification of images depends on the contemporary cultural situation of the viewer. The contemporary media are fascinated by early mugshots as historic artefacts. The Sun delights in deriding our ancestors "Shop the Edwardian Morons" is the jokey headline of a story about 100 year old mugshots from the Manchester police files. (Syson, 2011) The limitations in form and content of the mugshot make it an ideal tool for analysing the changing meaning of images over time with particular regards to the news media. The mugshot is a distinct sub-genus but the constancy of the classic close up 'head and shoulder' format lends itself best as an analytic tool. With little substantive to debate in the image as to the photographers' motivation or composition, arguments for certain accreted layers of signification are easier to make. The genus is one of the simplest amoebic forms of the photograph: a rectangle, a head and shoulders image of a human being. It is planned, posed but deliberately decontextualized. The photographer is required by the judicial authorities to capture the best detailed image of the suspect that is allowed in the circumstances. Its purpose is functional and bureaucratic primarily for future registration, identification and classification. The subject is likely to have been told not to smile and is expected to be as emotionless as possible. The lighting is set to aid accurate capture of the person's features. The edicts of the judicial authorities deter the photographer from the use of any technique to enhance or alter the image. There is a long running debate in photographic theory over the reality of the image, but the judicial client requires the mugshot to be as accurate portrayal of reality as is possible. The subject can show no personal belongings except the clothes they happen to wear. A cursory glance at a mugshot suggests it will carry little meaning other than a person has been arrested at some point. There is no pretence of art or creativity. It is a pure administrative form and its signification seems minimal.

Most photographs of people rely on the moment, the relationships, art, techniques, technical enhancement, movement, detail and a wide range of content to give meaning. Stuart Hall $(1973,188)$ says in his ground breaking essay on the semiotics of news photographs "News photo have a specific way of passing themselves off as an aspects of 'nature'. They repress 
their ideological dimensions by offering themselves as literal visual-transcriptions of the 'real world'." Many news photographs require a caption to provide the context and give the intended and specific meaning of the photograph. (It might be clearly a plane crash but the words are often needed to explain the when, where and how of the crash). Not so much the mugshot. Mugshots have their own limited grammar and often contain identifying signifiers. It can be the measuring stick, a board with a name and number identifying the subject; it might be two photos together: one face on, one a side profile shot. There may be a hint of institutional clothing, prison clothing or a white one piece suit. Sometimes they have none of the above and rely on the caption to elicit that it is a mugshot and not the closely related but the rather more innocent passport style portrait.

What this essay attempts to do is place the mugshot in a historical and theoretical context to explain the explicit and implicit meaning of the use of the genus in the media. I suggest that the mugshot's simplicity of framing and purpose is deceptive. Over 160 years the mugshot genre has come to carry an extraordinary array of meaning. It has been suggested it can used to humiliate and shame and even brand the subject. This essay seeks to examine the possibilities with a view to later deeper analysis of these elements. In part this paper discusses the way the mugshot has been used by the news media and as a journalist it is a reflexive exercise. Hall (1973, ): "It is necessary to distinguish two aspects of the signification of news. The first is the news value of the photographic sign. The second is the ideological level of the photographic sign." He adds: "By ideological elaboration we mean the insertion of the photo into a set of thematic interpretation which permit the sign (photo) via its connoted meaning to serve as the index of an ideological theme." The ambition of this essay is examine both but to especially tease out the ideological use of the mugshot, which as you will see leads to a disturbing conclusion. Hall observed in 1973 that even the simple mugshot has layers of meaning. Referring to a story where an image of an IRA leader Dutch Docherty was used in the press he observes. "Yet the passport photo, with its connation of 'wanted men', prisoners and the hunted, is not without ideological significance." Hall says that this image is also a universal mythic signs: "the face of all the 'hard men' in history, the portrait of Everymen as a 'dangerous wanted criminal'." (Hall, 1973)

\section{Hidden meanings and implications of guilt}

\section{Example One}

This is a Sun newspaper article featuring a picture of Robert Murat, once a suspect in the Madeline McCann case. ${ }^{\text {ii }}$ At its simplest, it is a photograph of a person. We can immediately recognise that it is a police photograph, or as they are more colloquially known, a mugshot, as key institutional signs are there: the deadpan expression of the subject, a vertical measurement stick for showing height, the neutral background and, in this case, a watermark that tells us the picture belongs to the Portuguese police. 


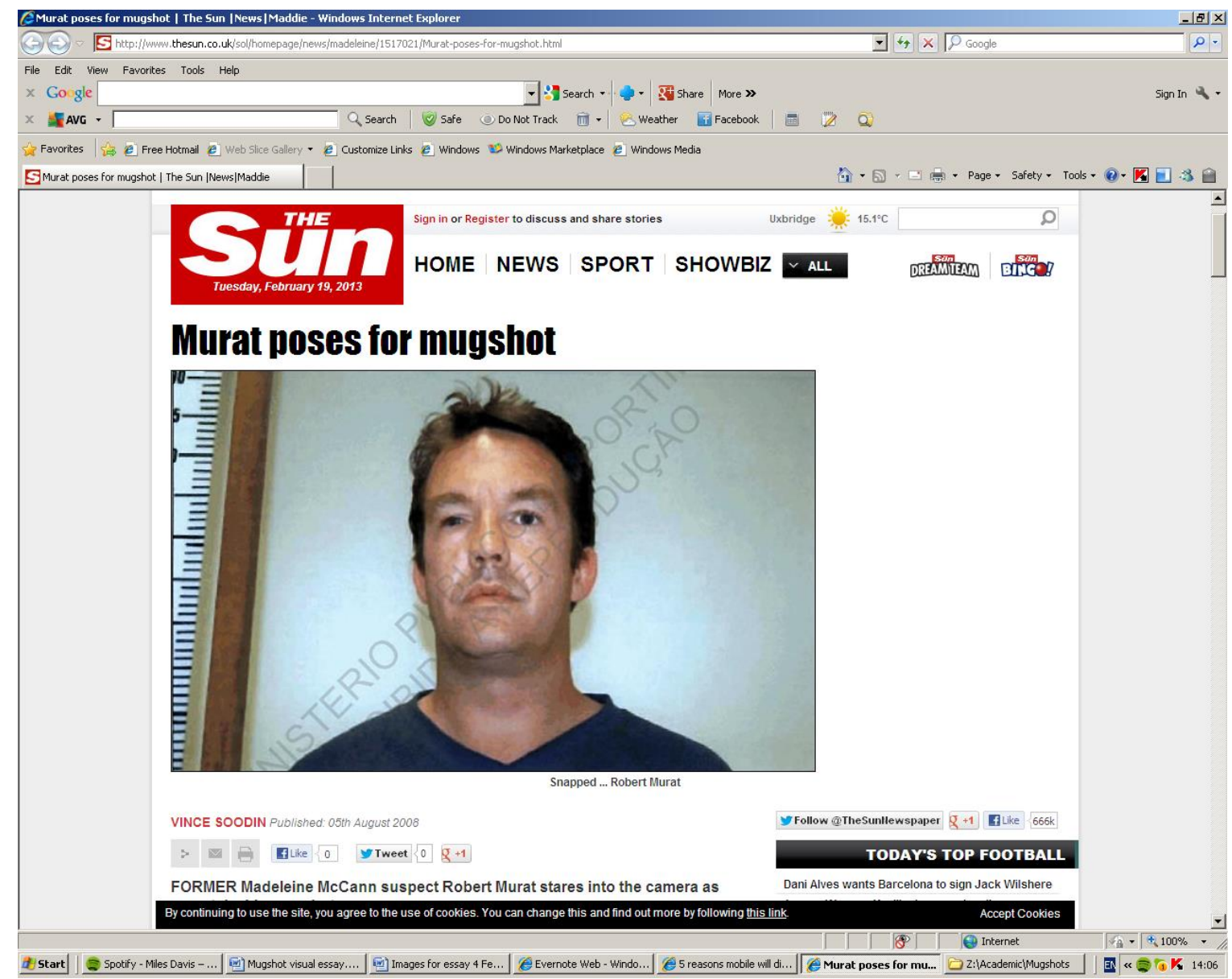

Used by the media the mugshot may be limited in variation but what is consistently signified is the person has been 'arrested' or has been a criminal, a signal we recognise even we do not recognise the subject. In this case, The Sun news report is presented as 'a story of record' to note the existence of the Murat mugshot. ${ }^{\text {iii }}$ But, as this essay will argue, it carries additional implicit levels of meaning and this is the real reason for its publication by The Sun.

Example Two

Winston Silcott was charged with the murder of PC Keith Blakelock after the Broadwater Farm riots in Tottenham Riots in 1985 


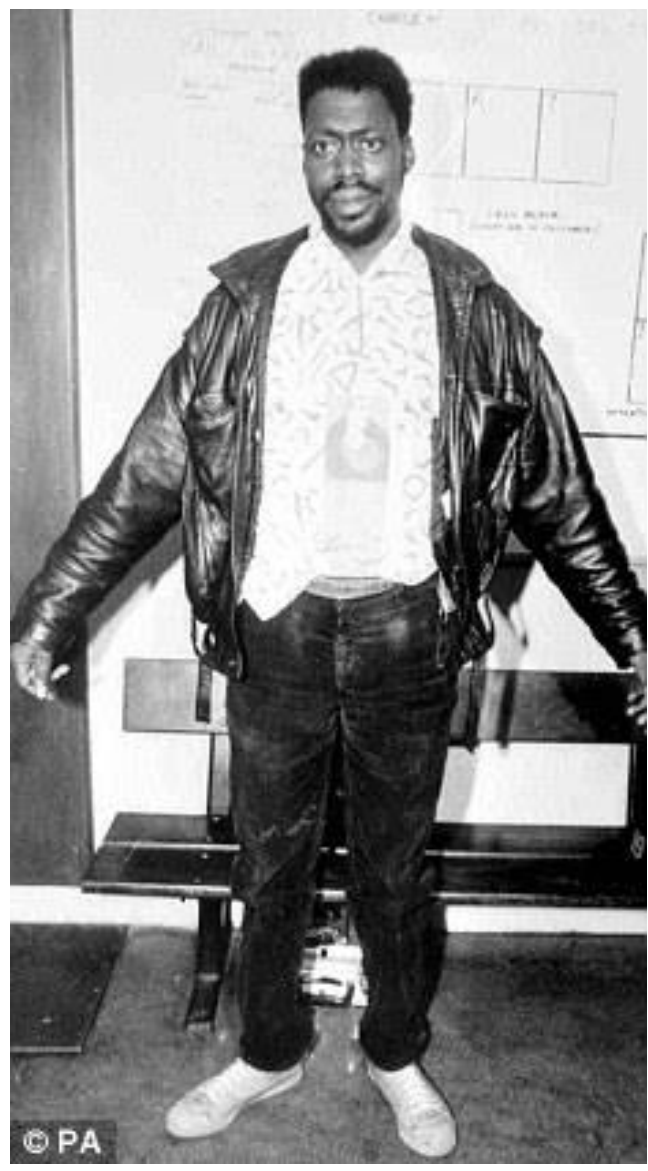

The Silcott photograph was taken at 4.00 am in the morning and released to the media. The Silcott family grew to intensely dislike that image as it was constantly used by the media even when he was freed on appeal. ${ }^{\text {iv }}$ The family offered and sent portrait photographs of Winston Silcott to the media that represented him in a more relaxed and ordinary pose. The mainstream media have ignored these photographs and continued to use the mugshot. The Silcott mugshot had become iconic. The implication is that it is how the media wanted their audience to 'read' Silcott. The question remains as whether Silcott image has come to represent 'bad' black Britain and there is a racial undertone to the image selection.v Milena Baum, vice-chair of pressure group the National Assembly against Racism, said Silcott would find it difficult to shake off his media character.

"Just as he was being released the media are showing the picture of Winston Silcott that makes him appear as someone who should be feared," she said. "This is an image that's been built up over the years and I think there is a belief among police officers that he is guilty of the Blake lock killing, even though he was cleared in a court of law."vi Silcott's arrest came just a few years after Hall et al (1978) work that suggested that the police and media had reconstructed the old crime of street robbery into the modern crime of 'mugging' with the implicit ideological subtext of demonising young black men.

Example Three

I'd like you to look at this image and consider what you see. What kind of person do you see? 


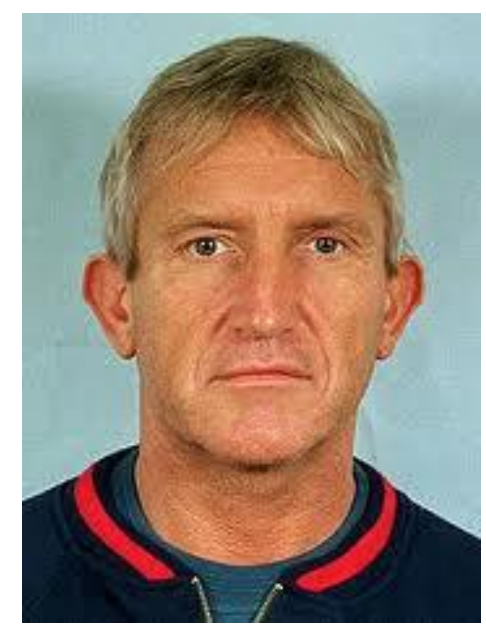

This is a photograph of Kenneth Noye, a career criminal currently in jail for murder. The picture may be a passport photograph, but it conforms to many of the conventions of the mugshot. This image was frequently used to accompany news stories on Noye, a man often identified as 'Public Enemy No 1' indeed it is used on the cover of a biography by that title. Used in the news media the image sends a very clear message out that this man has been arrested and that alters our response the person. The text will tell us that Noye can typify the classic type of indigenous gangland figure of the late 20th Century, handsome, clearly fit, brutal and ruthless. It is convenient for the news reporter to convey the Noye story to the reader. There is no apparent ambiguity. Knowledge of the person adds the layers of meaning. The passport photograph often serves the purpose of the mugshot though usually needs text to provide the meaning. The public have learnt the grammar of the mugshot and will understand when a portrait is cropped into a mugshot format or a passport is used, exactly what the publisher is signifying.

Mayr and Machin have emphasised the importance of the image to the way the news media report crime. "Stories are also more individualized and personalized and have far more shock or entertainment value when accompanied by images. The right image can elevate a criminal or crime victor to iconic status (e.g. the now infamous mugshot of 'moor murderess' Myra Hindley)." (Mayr and Machin, 2102, 11) Van Leewen, Machin and Kress are among those developing effective models to analyse images. I have drawn on these influences for this essay. One of the critical themes that runs through criminology and work on criminals is the personalisation of crime: that crime is the product of the individual who can be 'branded' as evil, insane, feckless etc and this is a distraction from the systemic and cultural context of the crime. Hall says that personalisation is "the isolation of the person from his relevant social and institutional context or the constitution of a personal subject as exclusively the motor force of history". (|Hall 1973, 183) The mugshot can be personalisation embodied. Yvonne Jewkes has pointed out "that media images are not reality, they are a version of reality that are culturally determined" (Jewkes, 2009, 37) Throughout, my presumption is that the mugshot genus lies on the intersection of many cultural, political, moral and philosophical fault lines of late modernity and its simplicity of form aids deep interpretation. Simplicity leaves less to contest and therefore can reveal more.

\section{The history of the mugshot}

Page | 6 
Prior to the 1840s identification of criminals was a local affair confined to recording text specifying features of suspects and criminals. It is not until the industrial revolution in the 19th century that there are mass population movements in England. This caused the judicial authorities difficulties in keeping track of known criminals. The era of invention was to bring a partial solution with the invention of simple and relatively economic photographic process by the Frenchman Louis Daguerre in 1839 and a similar contemporary development by the Englishman W.H. Fox Talbot. News processes allowed for multiple copies from each image and gave daguerreotypes a currency. It was the beginning of a visual revolution and the public immediately saw the potential of having relatively cheap portraits taken by these new cameras. Photographic studios sprung up in every High Street to service the new consumer need. Baudelaire was pithy on the indulgence: "A foul society has flung itself, like Narcissus, to gaze on its trivial image on metal." (Baudelaire, Salon of 1859). It would not be until the 1880 s that half tone technology allowed photographs to be easily reproduced in books and newspapers, then beginning to have mass circulations as the population became more literate.

While photographs are not in mass circulation in the period 1840-80 this period is important to track the major cultural changes that influence the police photograph format and deliver what we now think of as the classic mugshot format. Bate observed that for Foucault, the historian must excavate an archive to reveal not merely what is in it, but the very conditions that have made that archive possible, what he calls its historical a priori.

"In the first instance, the idea of photography as a type of "archive" has been around since the early days of photography. Whether it was (or is) an institution that wants to categorize its objects through photographs [...] or whether it is through individual photographers who construct a taxonomy of objects through their photographs [...] the aim is always the same: to provide a corpus of images that represent - and can be consulted about - a specific object. This means that photographs are almost always to be found within the conception of practice as an "archive"." (Bate, 2007, 3)

The story of the mugshot is central to the story of early photography, far more central than I, for one, had realised. One of Daguerre's supporters was Count Charles Tanneguy Duchatel, Interior Minister and in charge of the French Police in 1839. He successfully proposed that the method was so important to the State Daguerre should have a life pension for his invention. The early photographic critic Ernest Lacan suggested that such systematic photography of those arrested pre-supposed the idea of a criminal reoffending and of 'the habitual offender who is forced to recognise himself in this accusing image.' (Lacan, 1857, 39) The 'real' image of the criminal was important to help fulfil a basic human urge to seek to understand the motivation and character of the transgressor. German philosopher Arthur Schopenhauer notes in Parerga and Paraipomena (1851); "That the outer man is a picture of the inner and the face an expression and relation of the whole character, is a presumption likely enough in itself, and therefore a safe one to go by: evidenced as it is by the fact that people are always anxious to see anyone who had made himself famous by good or evil. Photography, on that very account of such high value, affords the most complete satisfaction or our curiosity." (Papi, 2006, 190) Photographic historian Graham Clarke says of early photographic portraits: “At photography's inception in the $19^{\text {th }}$ century the portrait was 
equated with oil painting, further encoding the dichotomy between the portrait in oils as an individual text and the photograph as part of a populist and democratic form of representation." (Clark, 1997, 103) Most of the earliest mugshots were taken and used by prison authorities. The police are slow to incorporate systematic photography of those they arrest and it only slowly becomes used as a tool for detection. The "painterly" nature of these early mugshots can be seen that of Thomas Haigh from the Tyne and Wear area it appears to be a portrait of a serious young man in a jumper and scarf. To my eyes he could have easily been a member of a louche artistic set.
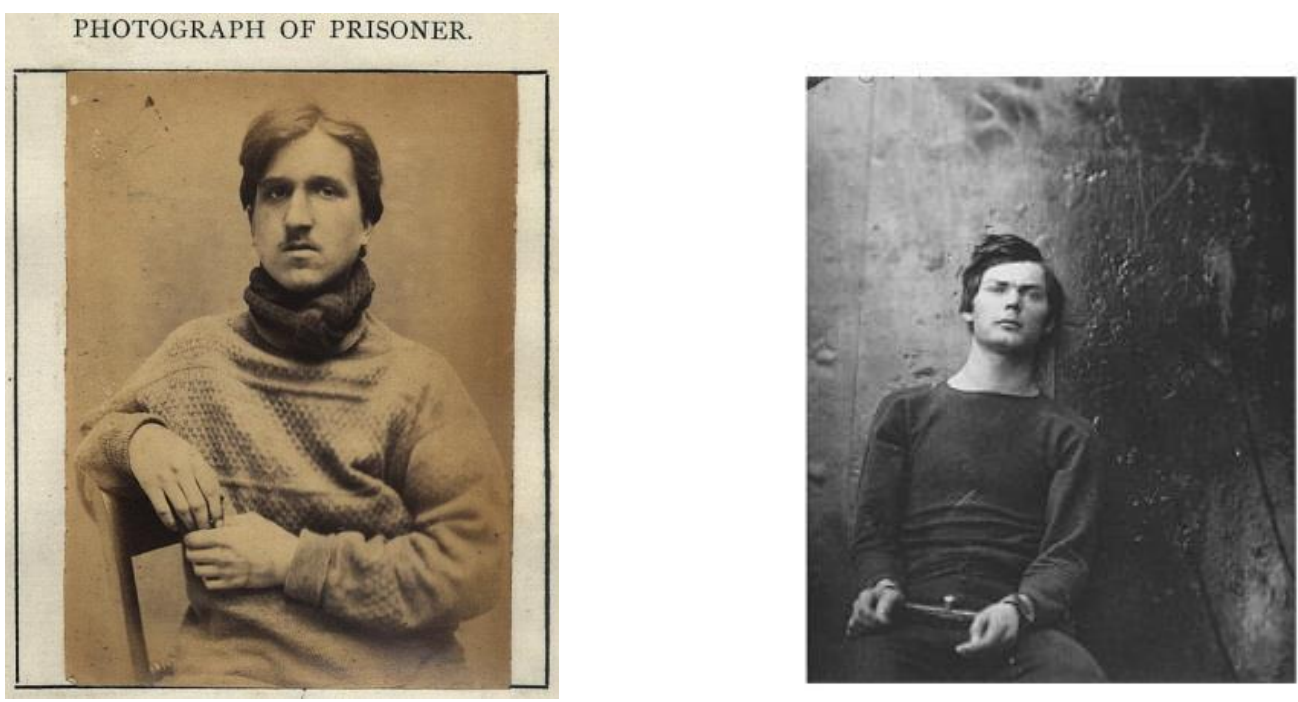

Fig: Thomas Haigh from Newcastle, arrested and jailed for theft. (source: awaiting permission of Tyne\& Wear Museums) Fig: Lewis Powell part of plot to assassinate President Lincoln (source: Library of Congress)

Even more striking is the 1864 picture of Lewis Powell, who was part of a plot to assassinate US President Lincoln. This instantly reminds me of a posed artistic portrait, a moody young man photographed with light source to the left, leaning against a textured backdrop. The signifier of crime here is the shackle that signified this man has a problem with the authorities. But as the century progresses we also begin to see another major cultural shift in the period towards a dehumanising format. A contemporary article in the British Quarterly Review (1866, Vol.44, p.379) by Robert Vaughan gives the used for taking and circulating the photographs: "Where the system is adopted the portrait of every criminal is taken as soon as he arrives at the gaol and prints from this negative are circulated attached to a printed form in which a description is given including details of age, height, complexion, hair, eyes, nose, whiskers and specific marks, and also the account which the prisoner gives of his place of birth, last residence, education, trade, religion etc. The circular containing the portrait and these particulars is forwarded by the governor to the governor of a neighbouring gaol, stating that the prisoner above described is in custody for trial and a request is added that if he is recognised as having been in custody before particulars may be forwarded and also that the circular may be forwarded to the next gaol marked in the route annexed". (Dukes, Proceedings, June 2013). What we see here is the driving force for the development of the 
modern system of criminal records; each record was adorned with a photograph of the subject.

\section{Spectacle}

As Foucault observed there is a historic relationship between crime, spectacle and punishment. Those deemed to have committed crime found that public humiliation was often part of the punitive process: the crucifixion of Christ on Calvary, the burning at the stake of Joan of Arc and myriad other examples. Foucault proposed the punishment had to be seen to be most effective: "The public execution is to be undertaken not only as a judicial; but also as political ritual. It belongs, even in minor cases, to the ceremonies by which power is manifested." (Foucault, 1977, 47) At the end of the 18th Century the notion of state surveillance had been articulated in Jeremy Bentham's Panoptican, a model prison where the authorities could constantly see the inmates without being seen. There was a belief that being watched would 'cure' their souls. Into the $19^{\text {th }}$ century these tropes permeate into attitudes to the newly invented photograph and a belief that the images could be used to 'watch' the criminal classes and cleanse their souls. Foucault said photography promotes 'the normalizing gaze, a surveillance that makes it possible to qualify, to classify and to punish. It establishes over individuals a visibility through which one differentiates and judges them' (Foucault 1977, 25).

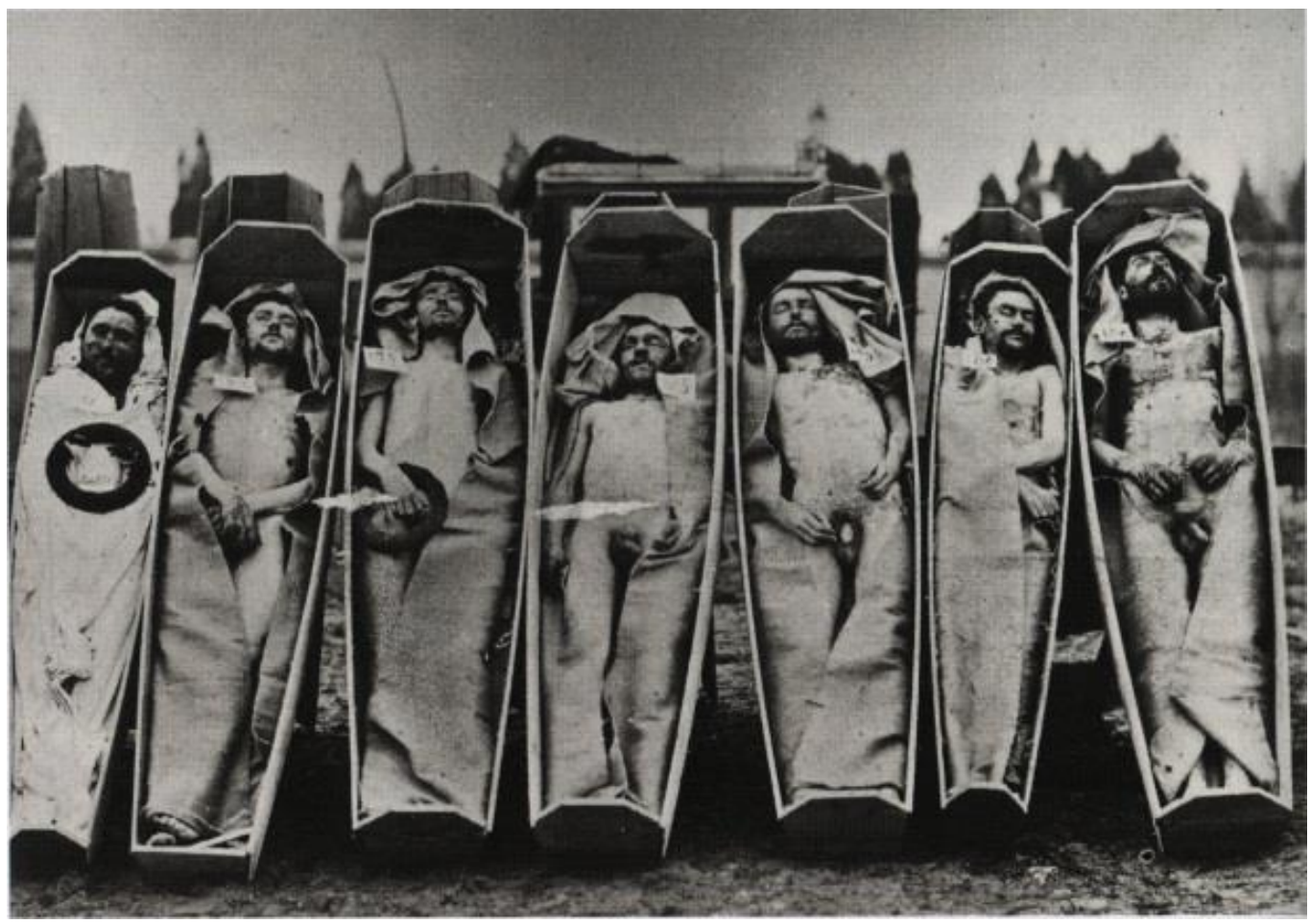

(Photograph attributed to Disderi)

The punitive power of the photograph was powerfully revealed in the aftermath of The Paris Commune where a revolutionary left wing government briefly ruled Paris in 1871 . The 
Commune was the result of an uprising in Paris after France was defeated in the FrancoPrussian War. The 'communards' manned barricades and were proud to photographed in their revolutionary act. However, when the French state managed to take back Paris from the communards the French authorities used the barricade photographs to identify, round up and execute the revolutionaries. Here we see the beginning of photography's role in the surveillance society. Photographers also went to the prison and took portraits of the arrested communards. But most powerfully, photographers took pictures of the dead, often executed, communards. The images of a row of coffins each with a dead communard are gruesome. In some the communards are naked or partially naked, their genitals visible. The photograph becomes the new and permanent method of the spectacle and the humiliation of those who have transgressed. The American essayist Susan Sontag observed "Photographs furnish evidence, something we hear about, but doubt, seems proven when we're shown a photograph of it. In one version of its utility, the camera record incriminates. Starting with their use by the Paris police in the murderous roundup of the Communards in June 1871, photographs became a useful tool of modern states in the surveillance and control of their increasingly mobile populations." (Sontag, 1977, 5) The communard photographs have a relationship with the mugshot, even if these photograph are full length, there is a sense it contains the mugshot of the dead person and the innovative permanent punitive function is there. In modernity the humiliation and spectacle of the punishment of transgression continues into death.

In 1854, Louis Mathurin Moreau-Christophe, a French Inspector General of Prisons proposed a biometricphotographic system for recording convicts and perceptively saw that the photograph had the capability to replace the branding iron - the traditional tool, but by then declining use, to mark the subject as a criminal. "Not only did prisoners fear the power of the camera, it marked their bodies with a stigma that was more than just symbolic; for in the developing culture of photographic circulation, the spectacle of the "brand" was extended and intensified,' observes Phil Carney. (Carney, 2010, 21)

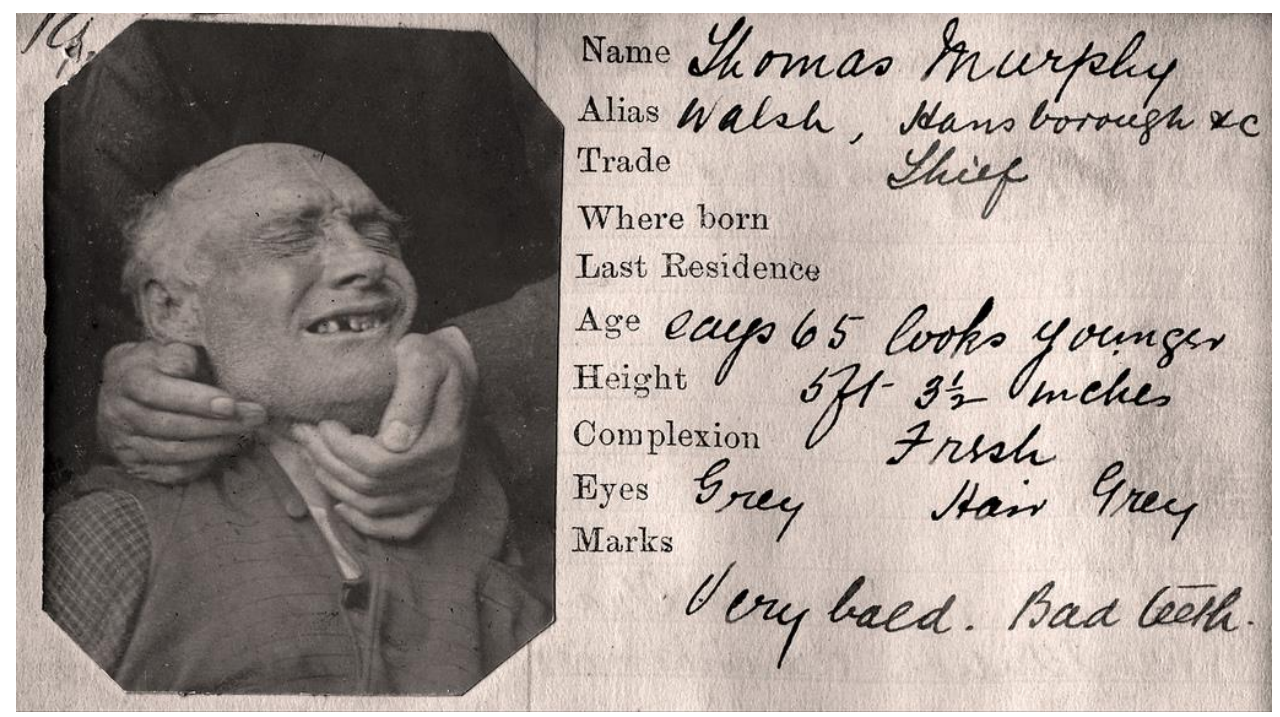


Fig: Thomas Murphy clearly did not want to be photographed. (Source: collection of Greater Manchester Police Museum and Archives)

Debord observed that in modernity we do not have to be present to participate in the spectacle: "In society where modern conditions of production prevail, all of life presents itself as an immense accumulation of spectacles. Everything that was directly lived has moved away into a representation." Debord argues that the history of social life can be understood as "the decline of being into having, and having into merely appearing." This condition, according to Debord, is the "historical moment at which the commodity completes its colonization of social life." (Debord, 1977) Cultural criminologist Phil Carney says: 'If the spectacle of public punishment had rapidly declined in the early nineteenth century, the new spectacle was to open up different forms of spectatorship of crime and punishment." (Carney, 2010, 20)

\section{Positivism}

We can see the anthropometric shift in the UK. The Dorset History Centre holds a later (1890s) police album containing full-face portraits of men, women and children who had been remanded for a wide variety of offences. The painterly portrait has gone, function has arrived. Each person has a label attached to their clothes with a number on it which is also noted in the Prison Register. In most cases the name of each individual, together with their crime and the date are written above the photograph. Mirrors are used to give a profile as well as a face on shot. Hands were thought to be a useful element in identification - they sometimes showed injuries or tattoos - but in the 1890s Home Office regulations proscribed photographing the hands.

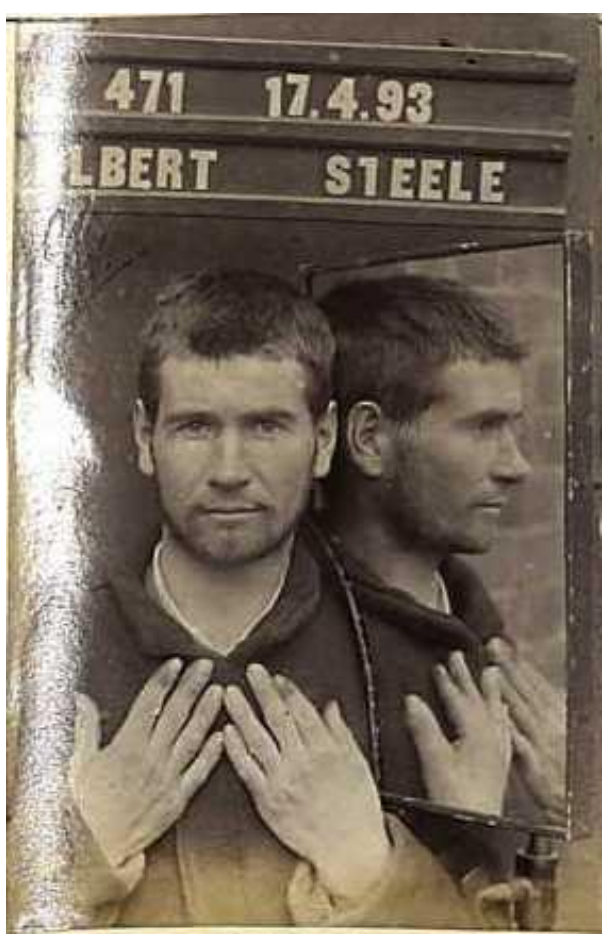


Fig: Full face and mirrored profile. This photograph has silvering of the paper which has affected many in the album and also shows the metal stand holding the mirror in position. No records of Albert Steele's stay in Dorchester Prison still exist. (Images by permission of the Dorset History Centre)

The invention of the photograph is integral to the dramatic rise of science and positivism of the $19^{\text {th }}$ century. By mid-century the intellectually engaged were obsessed with the possibilities of classification, whether it upon butterflies, flowers, ancient texts, the ill, the insane or criminal or colonial 'natives'. Photographs were often central to the recording process. One of the starkest examples of the time is a picture now owned by the Royal Anthropological Institute taken by an anonymous photographer of 'Ellen', a South Australian aboriginal woman in 1870. She is naked, turned sideways and holding a measuring stick.

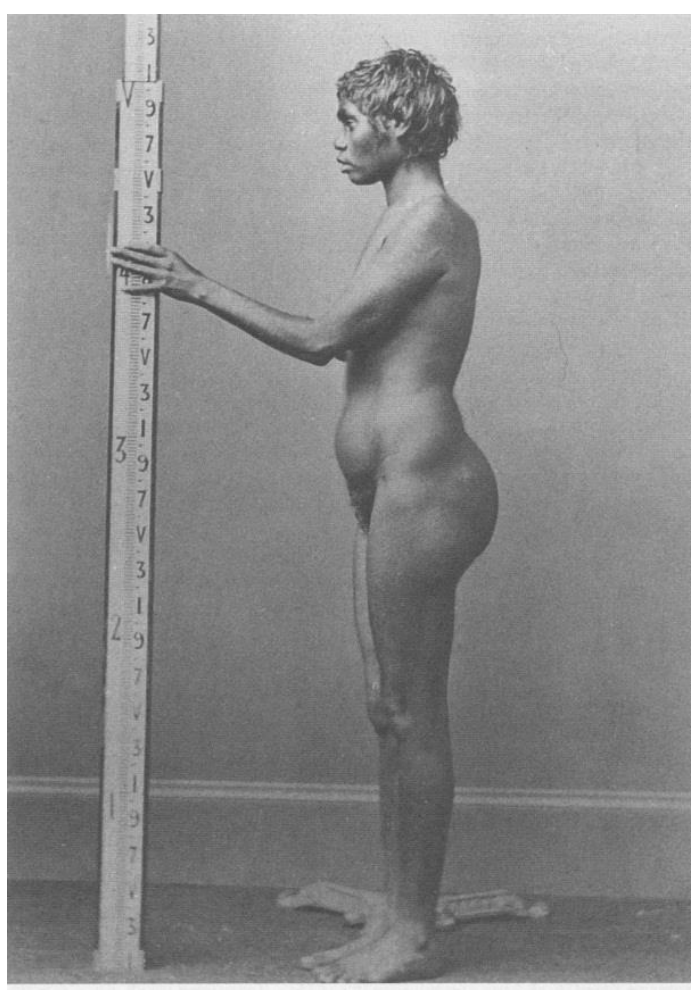

\section{Fig: Ellen (Source: Royal Anthropological Institute)}

Ann Maxwell says that aside from the anthropological use of these photographs: "Colonial photography too was in the business of confirming and reproducing the racial theories and stereotypes that assisted Europeans expansion." (Maxwell, 1999, 9) She says that most of these images were racist in tone and inflicted injury of the communities from which they were drawn. "Images of colonized people also had an effect on the predominately western audiences who consumed them. The visual representation of colonised people as savages not only helped to sustain imperialist expansion but also supplied Europeans with a new, empowering framework for identity based on racial and cultural essences, the effect of which are still evident today in the exploitative an discriminatory attitudes that continue to surface within metropolitan and settle-colonial societies.(Maxwell, 1999, ix) The anthropological 
photograph is being used to justify the right of colonialists to control others. This is a period of massive expansion of the empires of a number of European powers. (see also Hight $\&$ Sampson, 2004). The viewing of certain groups of humans as 'lesser' and to be classified and categorised is in full swing by the 1870s. It is a pursuit undertaken by people of higher class, usually well-educated and mostly men and all white. By classifying by race, class and gender the middle and upper classes were able to reinforce their own difference and distance. It is worth noting that whenever the elite are photographed in formal portrait it is at an angle of 45 degrees, a pose that harps back to the authorative construction of upper class portrait paintings of the pre-photography era.

The idea that criminals are somehow inherently different from the rest of society has probably been with us since the beginning of human society but by the 19th Century interested scientists endeavoured to turn this into a science. Photography was an enabler allowing classifiers to gather a large number of images of criminals to test their theories. Two scientists of the period stand out here.

Cesare Lombroso (1835-1909) an Italian criminologist and physician, was the founder of the Italian School of Positivist Criminology. From post-mortems and anthropometric studies Lombroso proposed that the 'born criminal' could be anatomically differentiated by such features as a sloping forehead, ears of unusual size, asymmetry of the face, jaw protrusion, excessive length of arms, asymmetry of the cranium, and other "physical stigmata". Lambroso believed this indicated criminals had defects that suggested that were a throwback to primitive forms of social evolution. He produced a book on his "L'Uomo delinquent" (The Criminal Man, 1878)

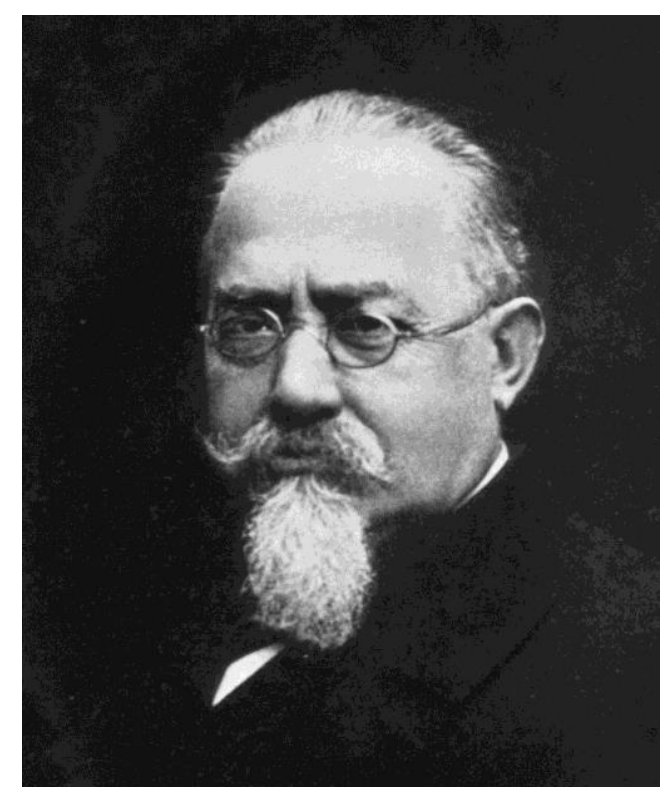

Fig: Caesar Lombroso ("The National Library of Medicine believes this item to be in the public domain.") 


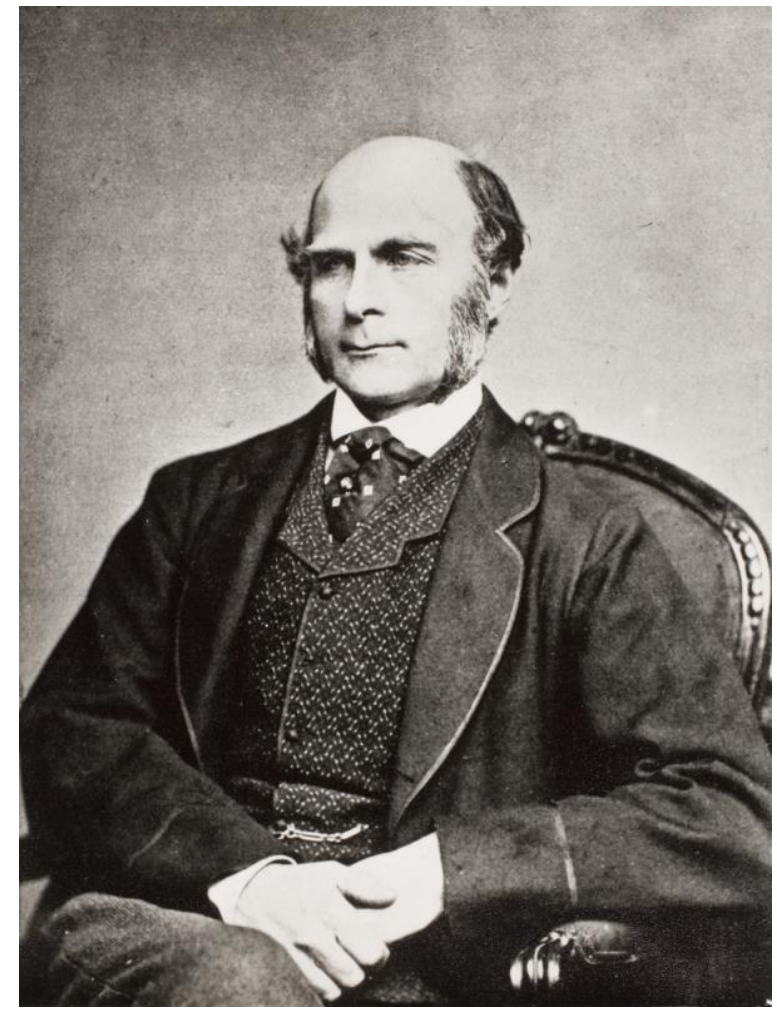

Fig: Francis Galton (used with permission of University College London)

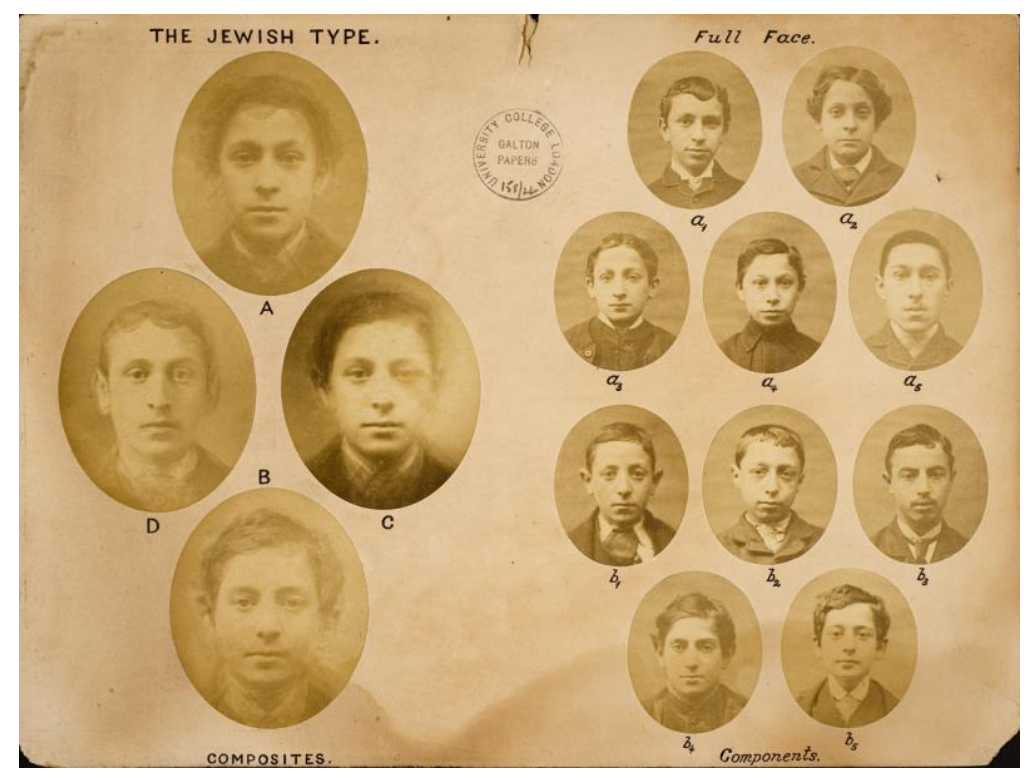

Fig: Galton composite image 1 (used with permission of University College London) 


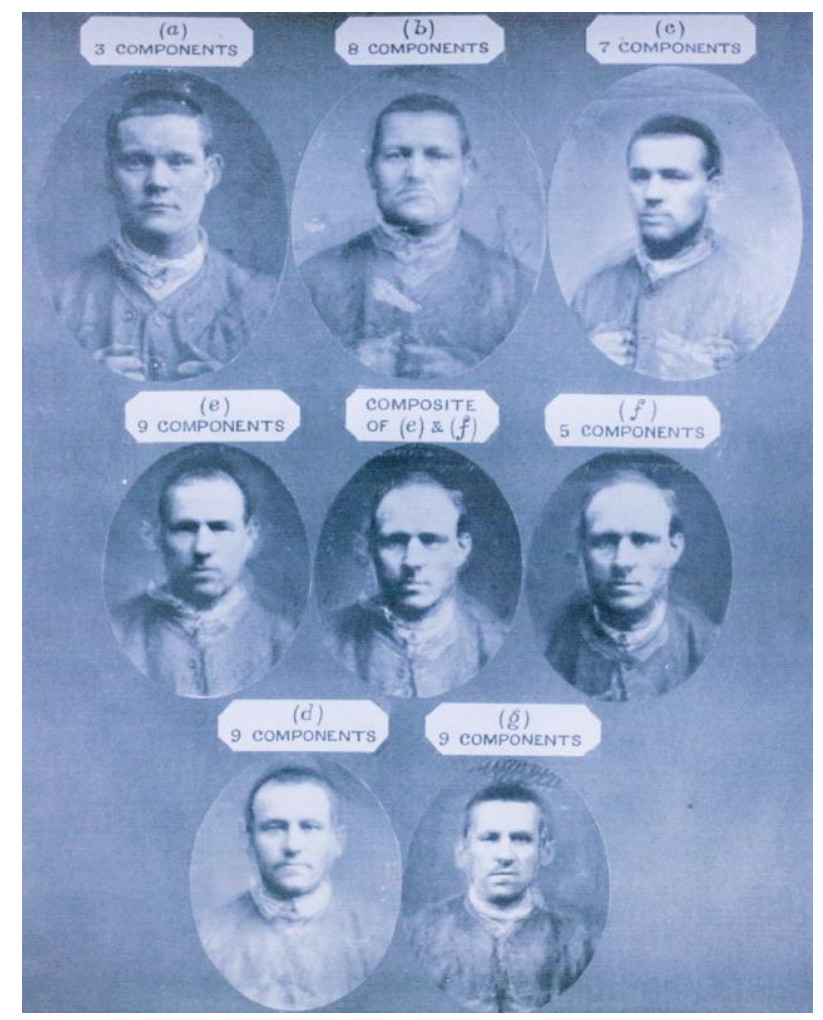

Fig: Galton compsite image 2 (used with permission of University College London)

Sir Francis Galton (1822-1911), a cousin of Charles Darwin, was an English polymath who devised a technique called composite photography. He superimposed multiple photographic portraits of individuals to identify a 'natural' kind, like Jewish men, criminals, patients with tuberculosis, onto the same photographic plate. He believed this would reveal the facial appearance of his subject as fitting into a 'central type'. From the 1880s Galton conducted extensive research, publishing his results and producing pages of images of how criminal bodies differed. ${ }^{\text {vii }}$ Galton hoped his technique would aid medical diagnosis, and even criminology through the identification of typical criminal faces. After many years Galton realised his experimentation was not supported by the evidence. Lombroso's research was largely discredited by the 1900s but by then these positivist ideas, though extreme and unfounded had taken hold.

\section{Race}

The use of photography to create cultural constructs, which demonised or 'othered' people, was already being noted by the fin de siècle. Positivist excesses were being challenged and one of the most perceptive critics was the black American civil rights leader W. E. B. Du Bois (1868 -1963) an American sociologist, historian, and Pan-Africanist who fully realised that photographs had the potential to stigmatise whole 


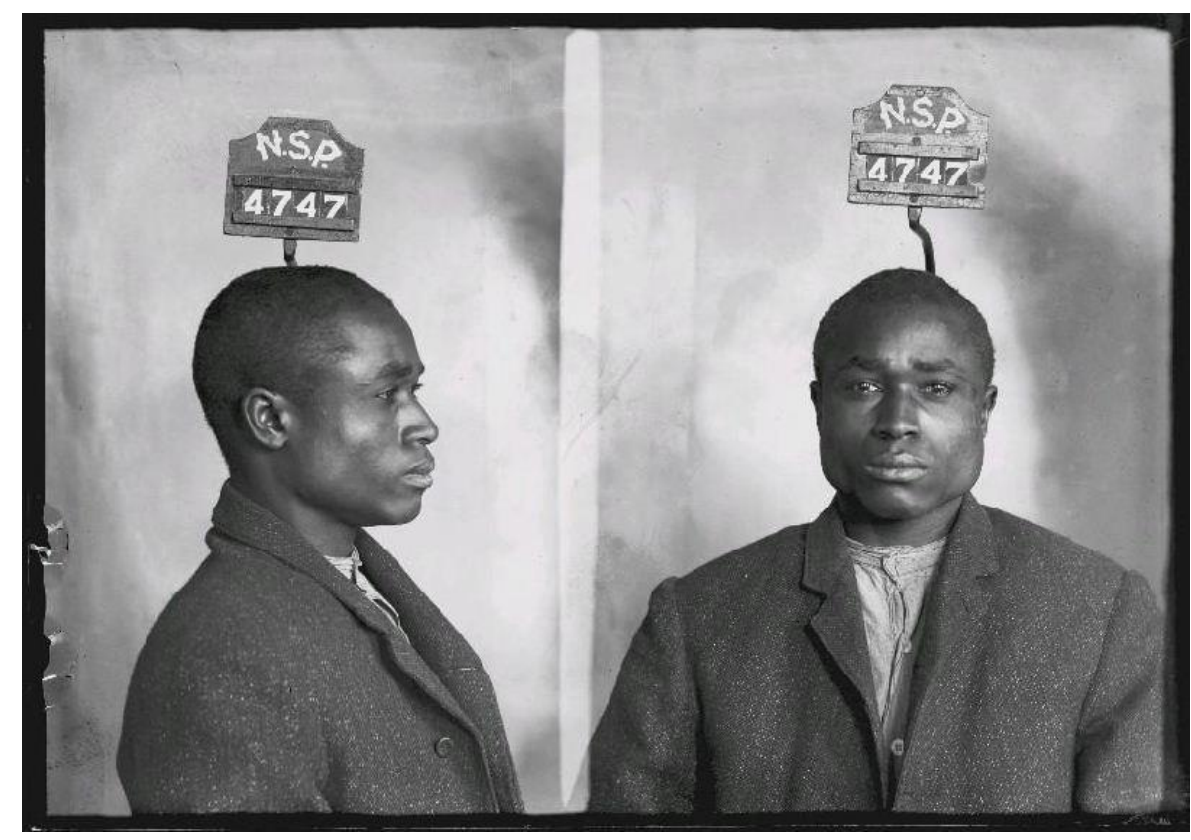

Fig: Cavalry Sgt John Reid was convicted of manslaughter for the death in 1906 of US Marshal Arthur Moss and sentenced to 7 years at the Nebraska State Prison. "Nebraska State Historical Society," the NSHS's identification number for the item used and the words "copy and reuse restrictions apply," and must be placed near the image and linked to this use policy (http://www.nebraskahistory.org/lib-arch/services/refrence/use_policy.pdf).

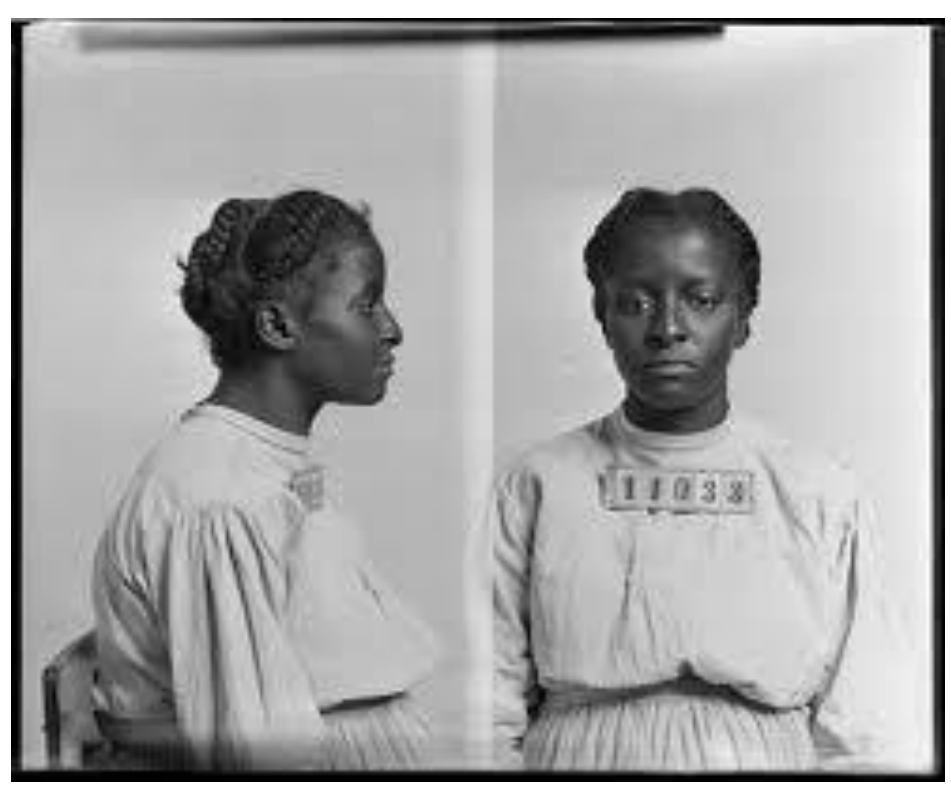

Fig: In October 1912, Mary Morst was sentenced by the Pittsylvania County Circuit Court to 18 years in the Penitentiary for murdering her husband. ( by permission of the Library of Virginia) 

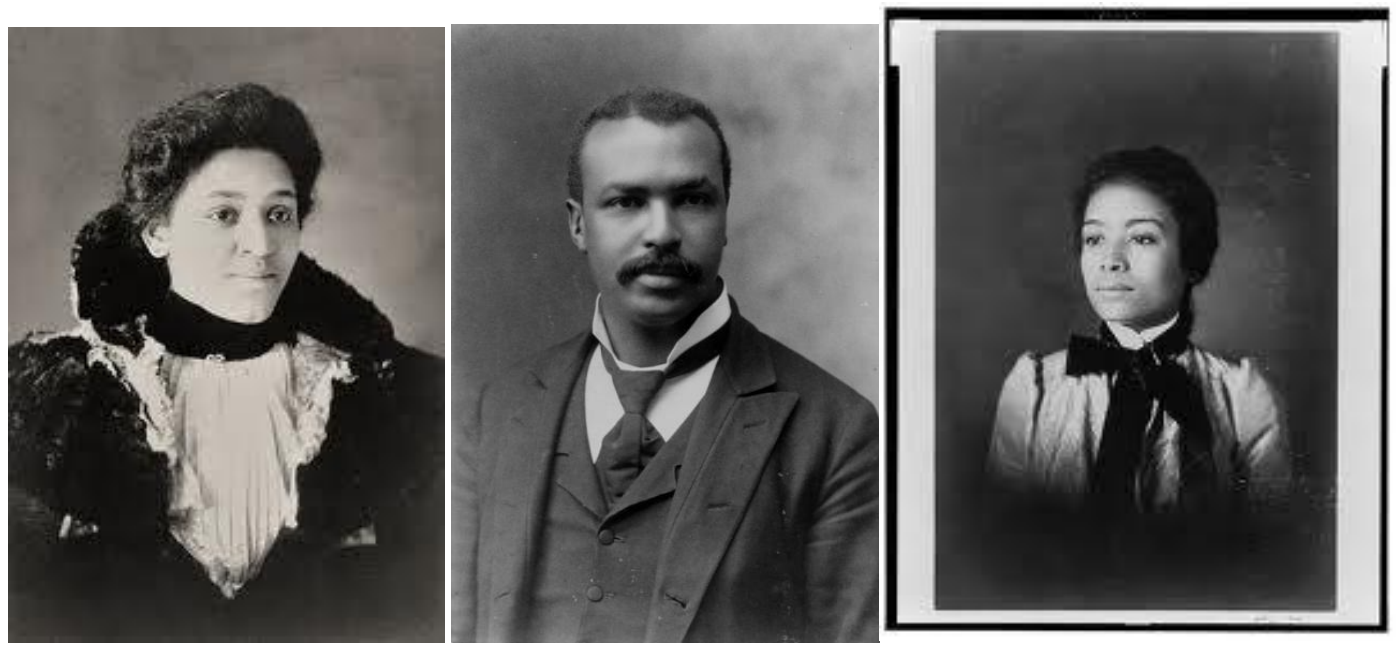

Fig: Images from Du Bois albums of African-Americans from the southern States. (Source: Library of Congress)

groups. Funded by the American government Du Bois lead a group of leading black American intellectuals putting together the Negro Exhibit for the 1900 Paris Exposition, housed in the Palace of Social Economy and Congress that was designed to show development of the African American people in the three decades following the end of slavery. As part of the exhibit Du Bois brought together 363 images of black Americans. Some are in the mugshot format and the photos were in albums reminiscent of the 'Rogue's Gallery' police mugshot albums of the day. Du Bois was acutely conscious of the black person's situation in a racist society “with a sense of always looking at one's self through the eyes of others". The modern academic Shawn Michelle Smith has suggested that Du Bois had used the mugshots format to mark the boundary between the criminals and middle classes. “Thus, as one moves through Du Bois' albums, one finds that the stripped down mugshot gradually fades into the middle-class portrait. I would like to suggest that, in situating these visual poles of identity in such close proximity, Du Bois' albums expose the dependence of middle-class identity on the counter-image of a criminal other. Indeed, Du Bois' photographs are unsettling because they signify at the limits of middle-class photographic portrait."

The implicit racism in the way that many photographs of 'natives' and 'criminals' were taken and used later becomes a theme in post-colonial theory. Hight and Sampson observe: "The photographers expressed distinctions between colonialised peoples and themselves ambivalently; as agents of colonial culture, they most often envisioned their subjects as objects of both racial inferiority and fascination. The photographers' perceptions of their subjects were influenced reinforced by a diverse array of familiar administrative practices, commercial enterprises, artistic and literary traditions, as well as the ongoing scientific investigation of racial types. That the photographers shared attitudes with other colonial structures made these images readily accessible to the imaginative conceits of a broad range of Western viewers.” (Hight and Sampson, 2002, 1-2)

\section{Fascism}


Post-World War One there was a major disturbance in the metaphysical continuum that was even to impact on the peculiar sub-culture of the mugshot. Notions of racial purity and eugenics as proposed by Galton and Lambroso among others had developed and found a natural home in fascism. The influential Kaiser Wilhelm Institute of Anthropology, Human Heredity, and Eugenics (KWI-A) was founded in 1927. Like many ideas taken to extreme, positivism developed but left human empathy behind. These ideas provided an apparent scientific basis to the creeds of National Socialism. The notion that some people are genetically predisposed to crime becomes the basis of a concept that an entire race, the Jews, is criminal and morally debased. The Nazi authorities set about classifying and making orderly, one of the worst genocides in human history. Classification allows for inclusion and exclusion.

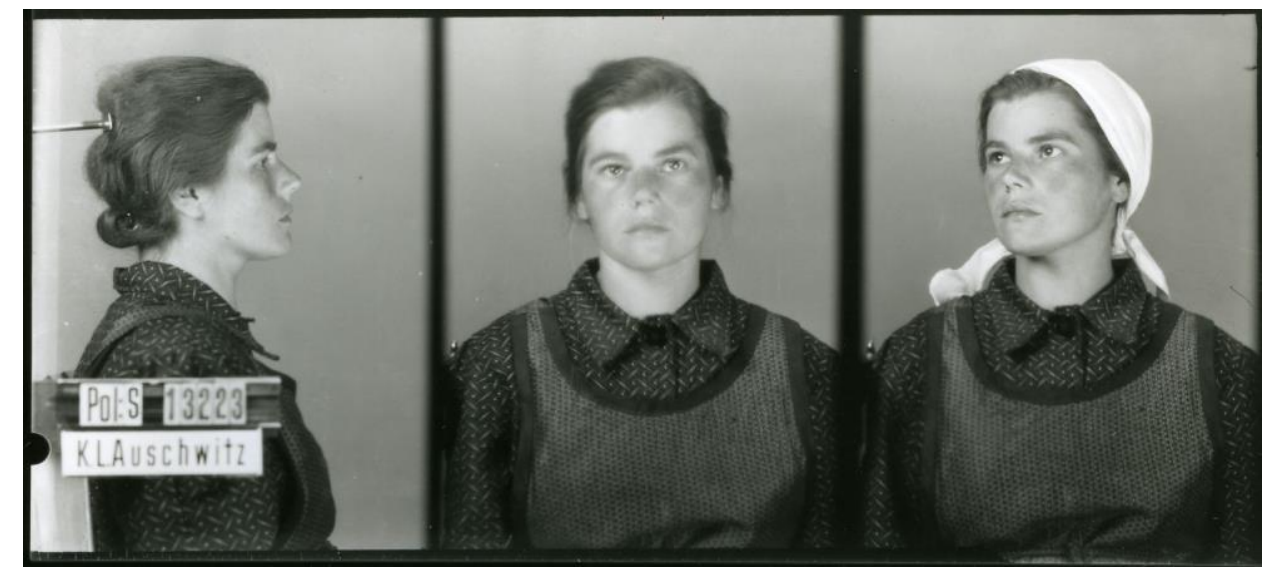

Fig: Auschwitz id image: Anica GRUDEN URISEK, no. 13223; Slovene; 14 years old; in Auschwitz since 31 July 1942; further fate unknown. (Published with permission of Archive of the Auschwitz-Birkenau State Museum)

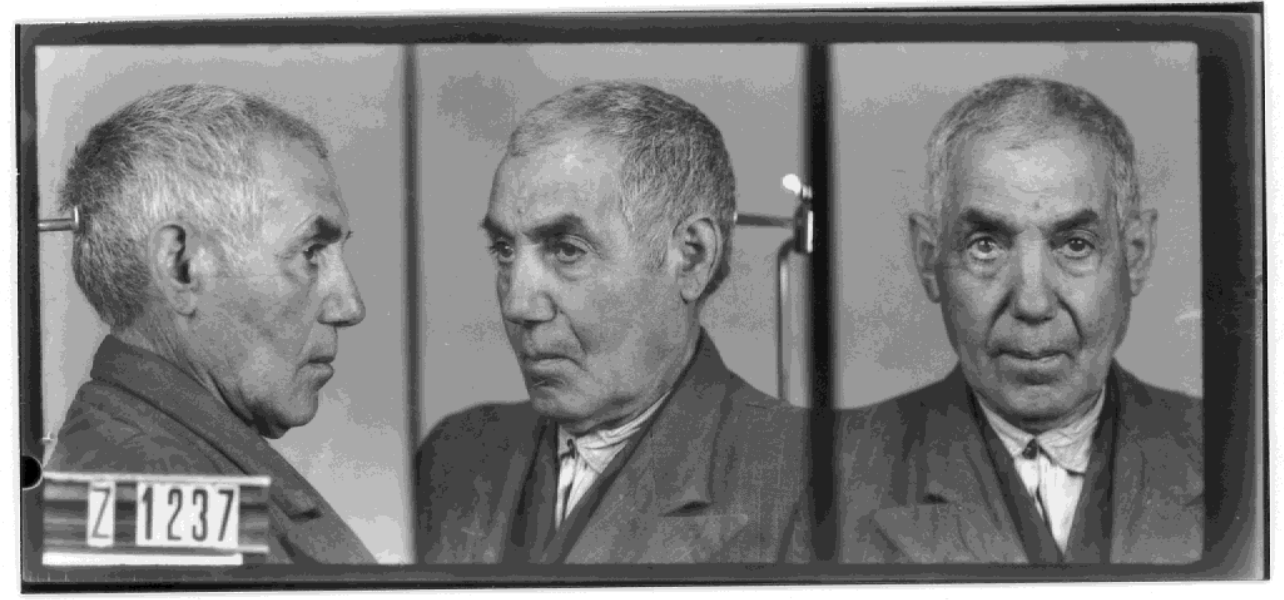


Fig: Auschwitz id image. Johann HOLOMEK, no. Z-1237, Roma; 70 years old in Auschwitz since 3 March 1943, further fate unknown. (Published with permission of Archive of the Auschwitz-Birkenau State Museum)

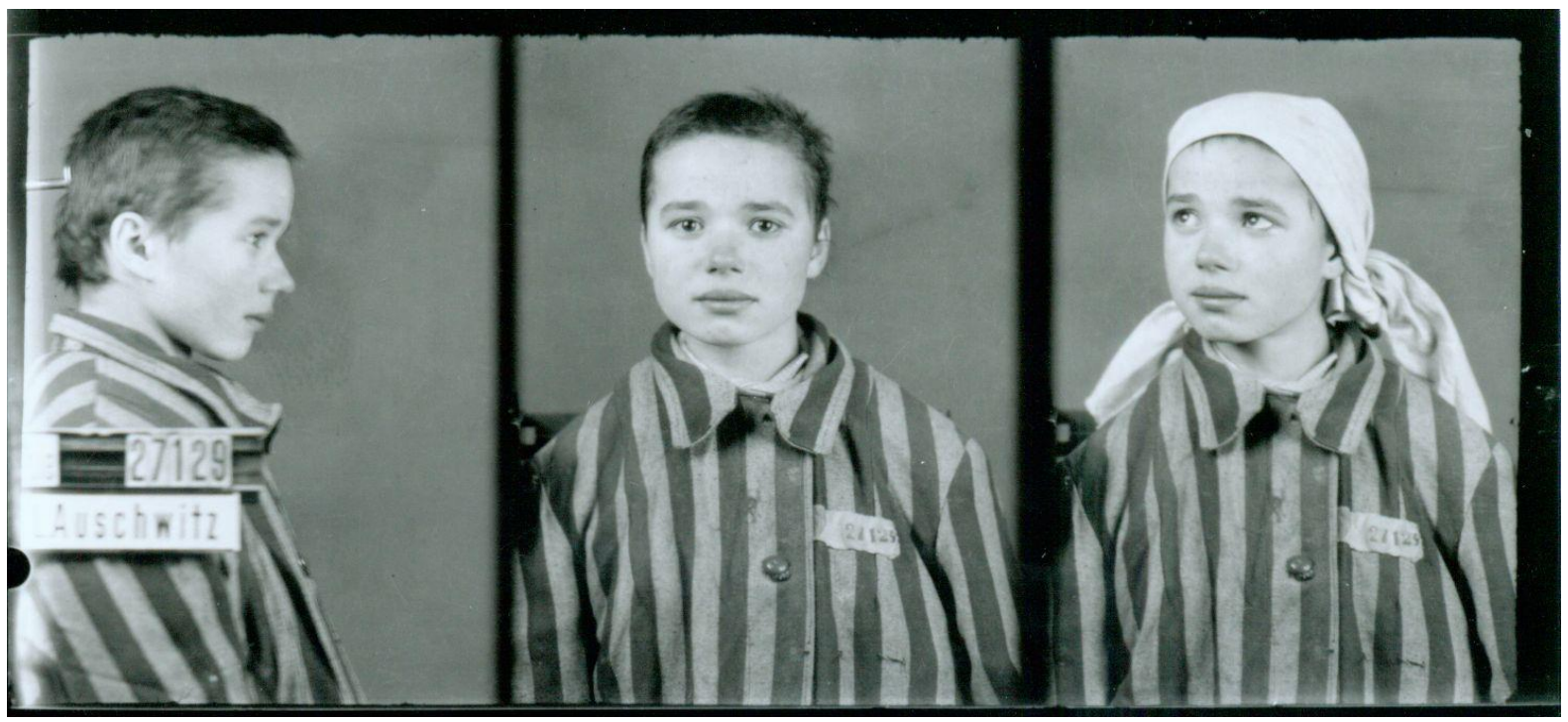

Fig: Auschwitz id image: Janina BLEIBERG, no. 7537; Jew from Poland, 16 years old; in Auschwitz since 30 May 1942; survived. (Published with permission of Archive of the Auschwitz-Birkenau State Museum)

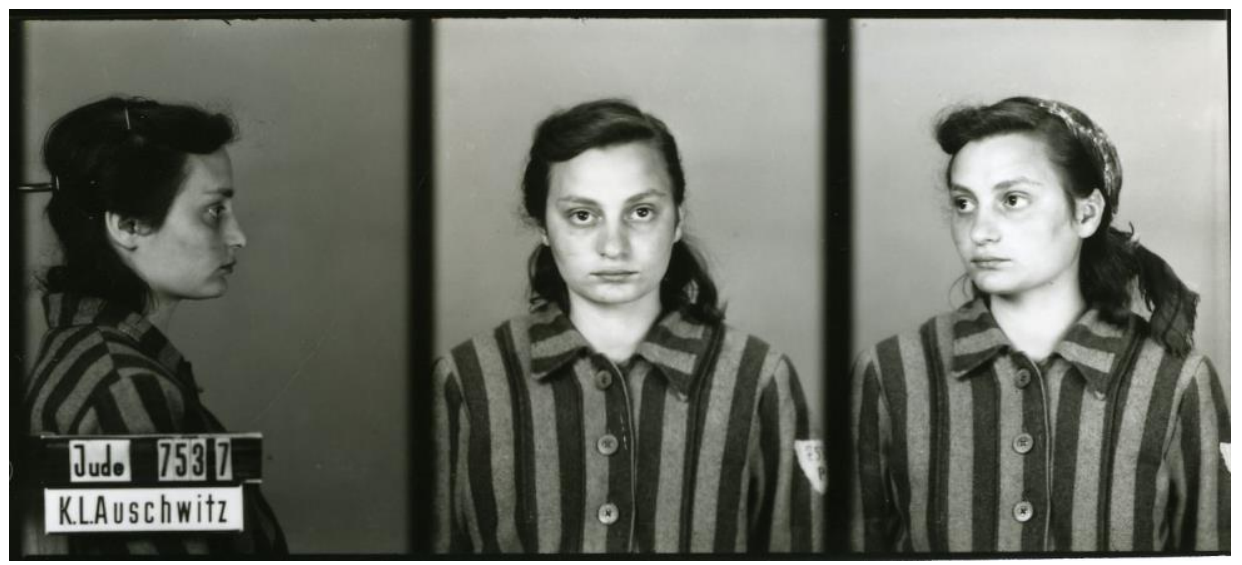

Fig: Auschwitz id image: Krystyna TRZESNIEWSKA, no. 27129; Pole; 13 years old; in Auschwitz since 13 December 1942; died 18 May 1943. (Published with permission of Archive of the Auschwitz-Birkenau State Museum)

Each inmate in Auschwitz concentration camp was photographed in prison uniform in classic mugshot profiles. In these archives we can see how the photograph signified the criminalisation of an entire race. ${ }^{\text {viii }}$ Stalin was to do something similar with the political dissidents sent to the Gulag. The use of images in fascism and the Holocaust is the subject of extensive academic discussion but it worth noting the role of the mugshots as both in a bureaucratic but also in a propaganda role. Spielberg's Holocaust masterpiece "Schindler's 
List" opens with shots of typewriters to denote the bureaucratic underpinning of genocide. Each was methodically photographed a categorised criminal for being a member of a proscribed race or for being different or having different views.

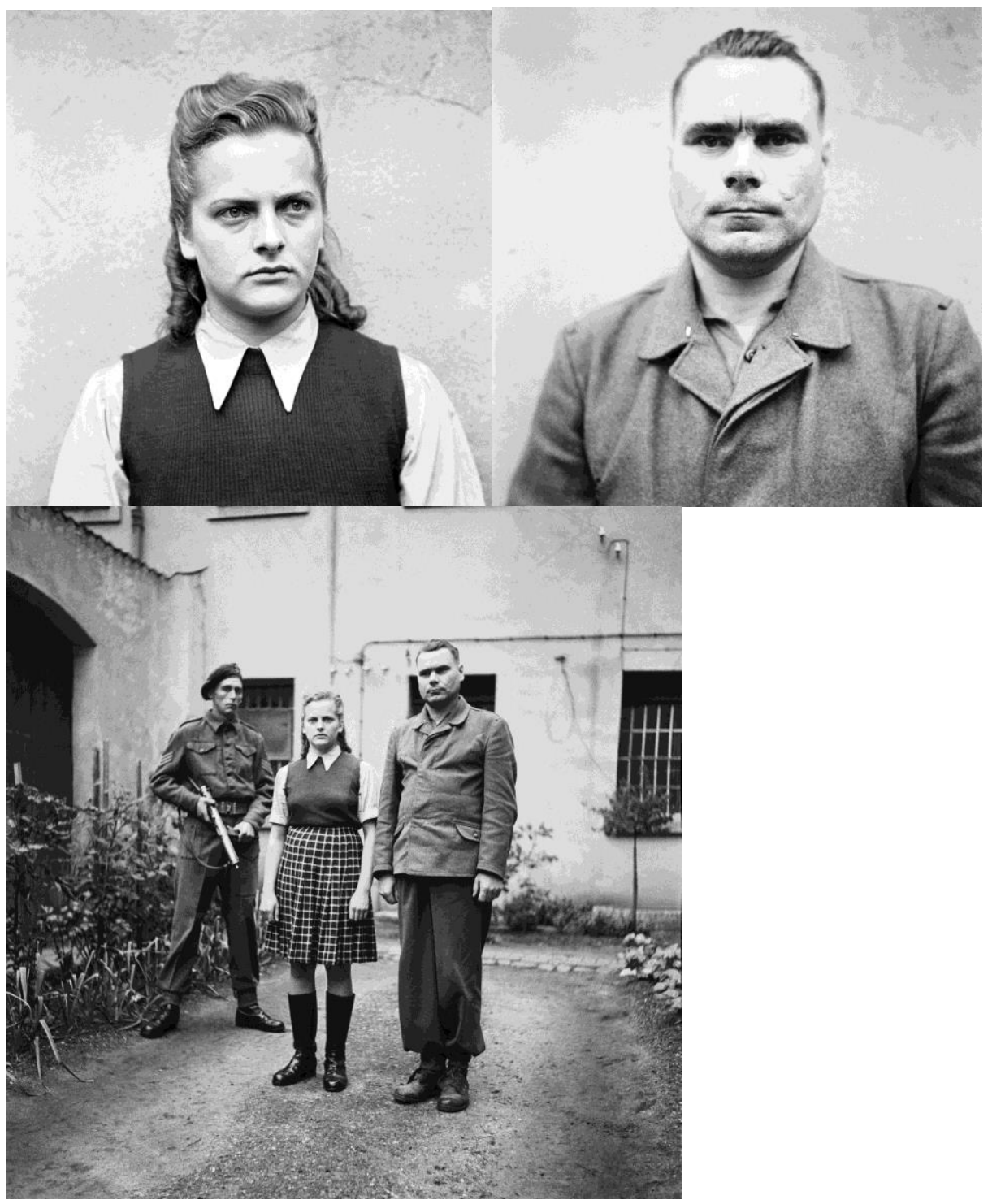

Fig: These are 1945 judicial photographs of Joseph Kramer, the commandant of Belsen and Irma Guese one of the women warders noted for her cruelty. (Source: Imperial War Museum)

The pendulum swings in 1945 when staff of concentration camps are arrested and tried. It would be hard to argue that their criminality is a cultural construct rather one of basic human values. Both were hanged. But ideology is still present here in the question of who is chosen to blame for Holocaust. Here we have personalisation, the functionaries are blamed but what price does the wider culture pay for dehumanisation. Who creates a climate of intolerance to the 'lesser' and how are they brought to account?

\section{The classic mugshot}

By the 1900s the police mugshot form had been established as we now know it. The terms of the format and its modalities are mostly set. They were to remain restricted to the black and 
white image for many years. The mugshot's function is primarily bureaucratic and positivist. Whether it is a better format that the earlier 'painterly' images is open to discussion. It is arguable that the earlier images, with the subject in a slightly more relaxed pose, tell us more about the individuals. In the same period we see the rise of the mass literacy and mass newspaper markets with the mugshot used to portray visually the accused. Hall suggested the news media use photos of people - even the passport type and size to "support the function of 'grounding and witnessing': this is the man we are talking about, he really exists.'(Hall, 1973) The layers of meaning are though beginning to accrete. The mugshot now has baggage when published in the popular prints. It was established as a means of spectacle, shame and punishment. "It was through the body that nineteenth century society aimed to know, to punish, to exclude and beleaguer, to reduce and to make subject to law." (Frizot, 1998, 260)

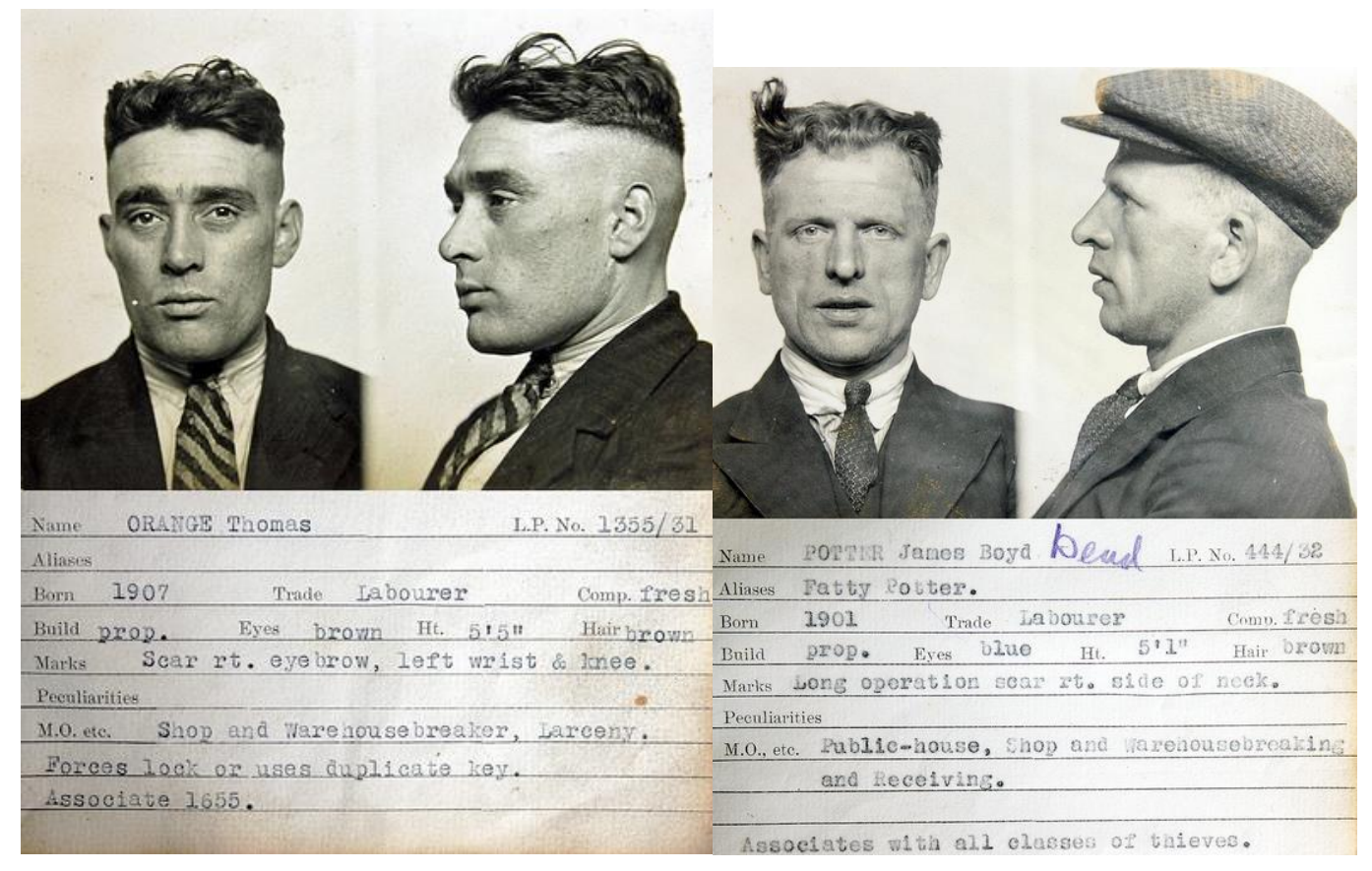

Fig: Police album from Newcastle upon Tyne 1930s. (Source: Tyne and Wear Museum archive)

Tagg says of the mugshots taken of those in all state institutions and not just prison: "If in the late decades of the nineteenth century, the squalid slum displaces the country seat and the 'abnormal' physiognomies of patent and prisoner displace the pedigreed features of the aristocracy, then their presence is no longer a mark of celebration but a burden of subjection. A vast repetitive archive of images is accumulated in which the smallest deviations may be noted, classified and filed. The format varies hardly at all. There are bodies and spaces. The bodies - workers, vagrants, criminals, patients, the insane, the poor, the colonised races - are taken one by one: isolated in a shallow contained space; turned full face and subjected to an unreturnable gaze; illuminated, focused, measured, numbered and named; forced to yield to the minutest scrutiny of gestures and features." ( Tagg, 1988, 64) We can also see that the 
mugshot when published outside the institution, as proposed by Hall, has an ideological subtext.

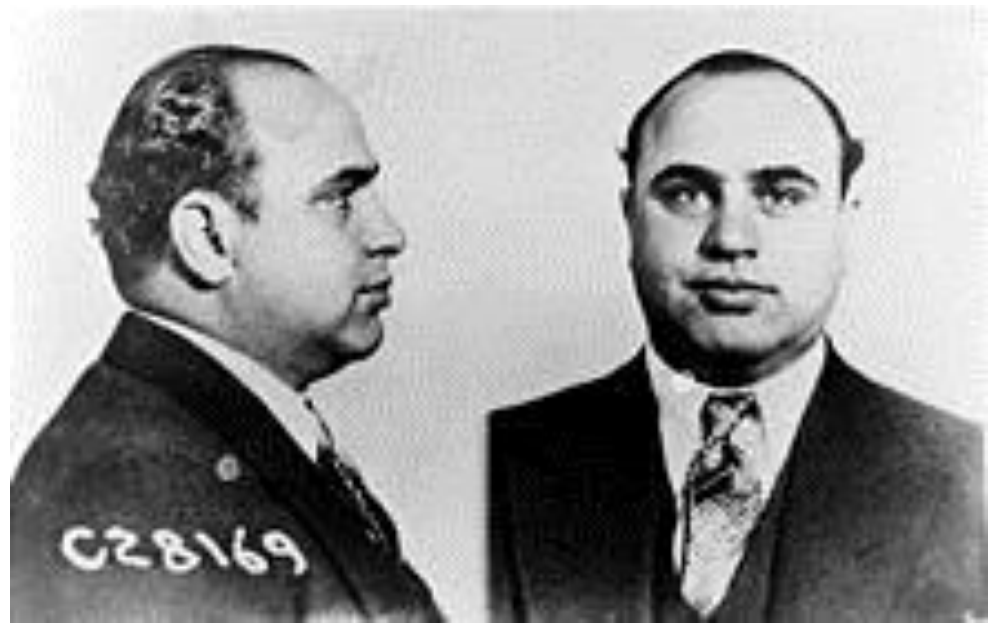

Fig: The gangster Al Capone (source: Library of Congress)

In the 1930s in the US Henry R Luce created Life (and later Time), the glossy magazine, as Gilardi writes his, "Incredible fortune was based largely on agreed journalistic appropriation of police photography." (Gilardi, 2003) Pictures of gangsters came of age, whether as wanted pictures, mugshots or death shots. To complement mugshots came the work of Arthur Fellig (1899-1968), known as 'Weegee'. Working at the height of prohibition a news photographer he is known for his stark black and white street photography. Weegee worked in New York as a press photographer during the 1930s and '40s, and he developed his style by following the city's emergency services. His work depicted urban life, crime, injury and death.

The creative revolution of the 1960s sparked new directions for photography. In the UK working class boy made photographer David Bailey is recording the collision of pop culture, crime and class. Among his most famous images are those of the gangsters, the Cray Twins, also from the East End. His photographic art records, but has also been accused of dignifying and glamorising people who are in fact murders and extortionists. But it was a heady mix at the time. It is only later in the 1960s that the Krays are arrested. The news media which were concerned about the Krays cult status equally enjoyed knocking the East End upstarts off the pedestal after their arrest. 

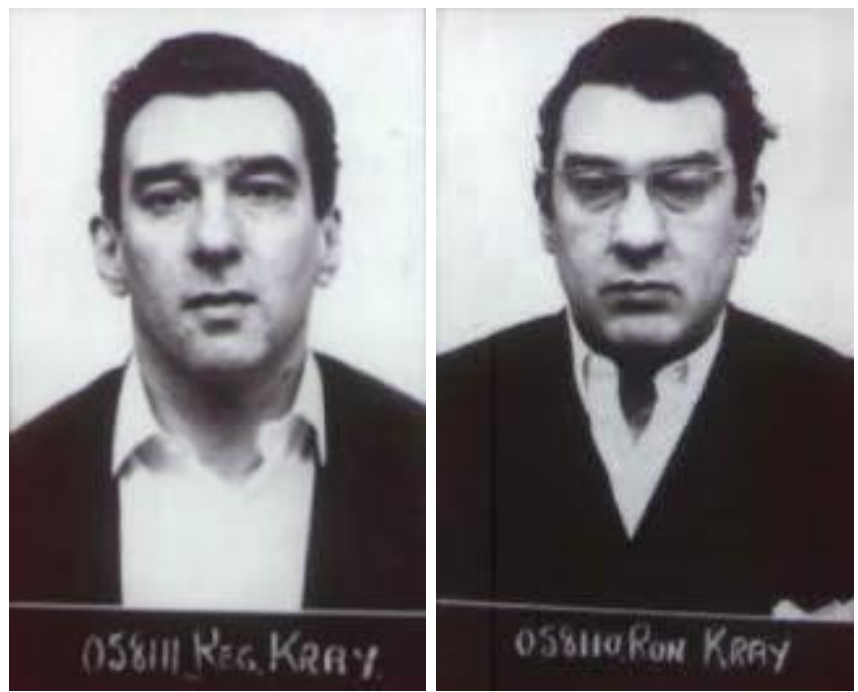

These classic mugshots of twins are counter iconic images to the Bailey images. This is the image as a statement of power and humiliation the power of the state to deal with transgression. As with so many mugshots, as Al Capone, we see the once powerful visually reduced to a captive not of just the photograph but of the state.

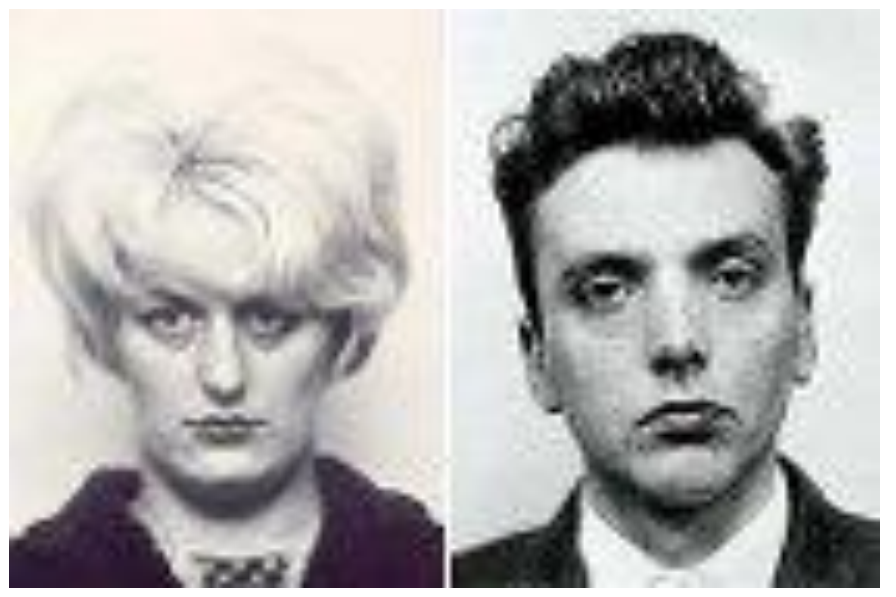

The 1960s also see the other iconic mugshot duo, Myra Hindley and Ian Brady who are convicted in a very high profile trial of kidnapping and murdering young children. It is coincidentally the time when sociologist begin to consider the role of transgression and deviance in society.

\section{Gender}

Women have always been subjected to mugshots but in numbers reflecting their lower offending rates. Their offences also tend to be lesser. Myra Hindley was one of the exceptions. Sociologist Chris Jenks uses the Hindley mugshot as the cover of his 2003 book Transgression. "Time has done little to diminish the public interest in the UK the ritual slaughter that came to be known as the 'Moors Murders', he says. "Beyond this catalogue of 
transgression (the murders), what perhaps shocks our taken-for-granted typologies most is that Hindley is a woman, and was, at the time, an attractive young woman. How could this be so?" Jenks makes the point that that society cast her as a 'monster' rather than woman to explain the extent of her transgression. Hindley, though is not unique, Rose West's involvement with her husband in a series of horrific sexually orientated murders was nearly as disturbing. Jenks point is that we have ways to expel those, from our communities who commit horrific acts, from our lives and minds. "We have symbolic mechanism to enable this and the creation of 'monsters' is a powerful one." Jenks says what makes Hindley image so powerful is that may represent us or someone we know.

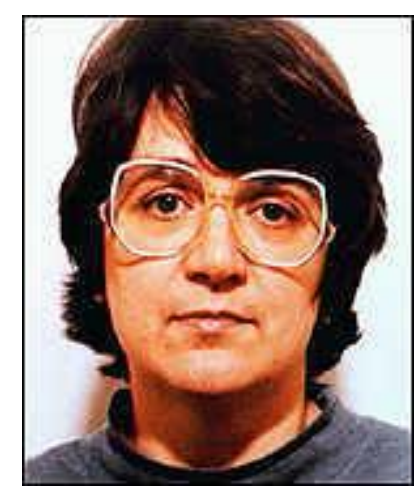

"Transgression is part of the social process, it is also part of the individual psyche. Our analytical purpose is to realise its cultural context and its socially constructed meaning. Practically this may mean that a defining feature of late-modern society is that our actions are organised through a stern paradox. Namely that people (sometimes 'monsters' but often people like ourselves) who feel trapped, threatened or violently constrained by external forces beyond their control seek excessive and transgressive experiences which, in some cases are even more threatening to their survival and, tragically in many cases threatening to the survival of innocents also." Hindley's image also brings to the fore a subterranean element of mugshot culture - sex. We can't know for sure as it remains within the male psyche but can there be much doubt that men find mugshots of arrested women fascinating. These are after all "bad girls" and therefore, it could be inferred, understand sexual transgression. The mugshot reveals the male control over women. It is to crime and surveillance that feminists have turned to explain the way men consume images of women and that it can be different from the way women look at pictures of men. Friedburg says 'The panoptic gaze has been invoked by feminist theorists to underline the one-way power of gendered looking, where women have internalised the voyeuristic gaze and are always subjectively 'objects of the look'. As we examine divergent models of the observer in modernity, a refutation of theories of the panoptic gaze will have significant ramifications on accounts of gendered spectatorship." (Friedberg in Mirzoeff, 2013, 404)

\section{The Mugshot in the contemporary media.}

Celebrity 
The rise in interest in the celebrity mugshot parallels the late 20th $\mathrm{C}$ obsession with celebrity. Marshall McLuhan was one of the first to see that the photograph commodified the bodies of the famous, and called these photographs 'Brothels without wall'. ix 'For McLuhan the photographic image of fame delivered darker desires. The expansion of celebrity into new fields after the Second World War gave this meretricious commodification another twist in the birth of the paparazzi,' says Phil Carney. $(2010,26)$

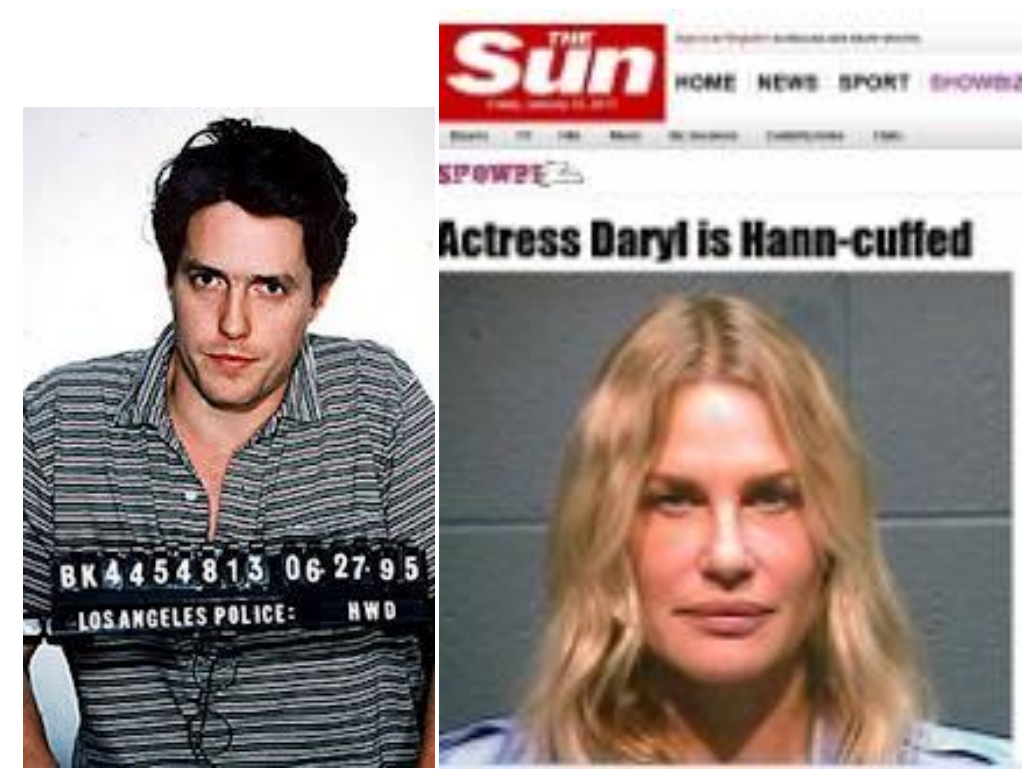

Fig: Hugh Grant from 1995 after an incident with a prostitute in Los Angeles. Fig: Daryl Hanna was arrested after a protest.

In the United States there are now millions of mugshots online. In many ways mugshots remind of me and counterpoint with the Dutch photographer Rinieke Dijkstra's photos of indifferent individuals - but mysterious. It is only when the anonymity is removed that iconic status can occur. 


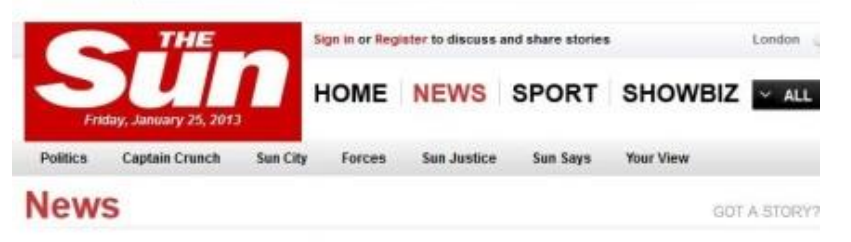

\section{Thief's tattoo prison pics}
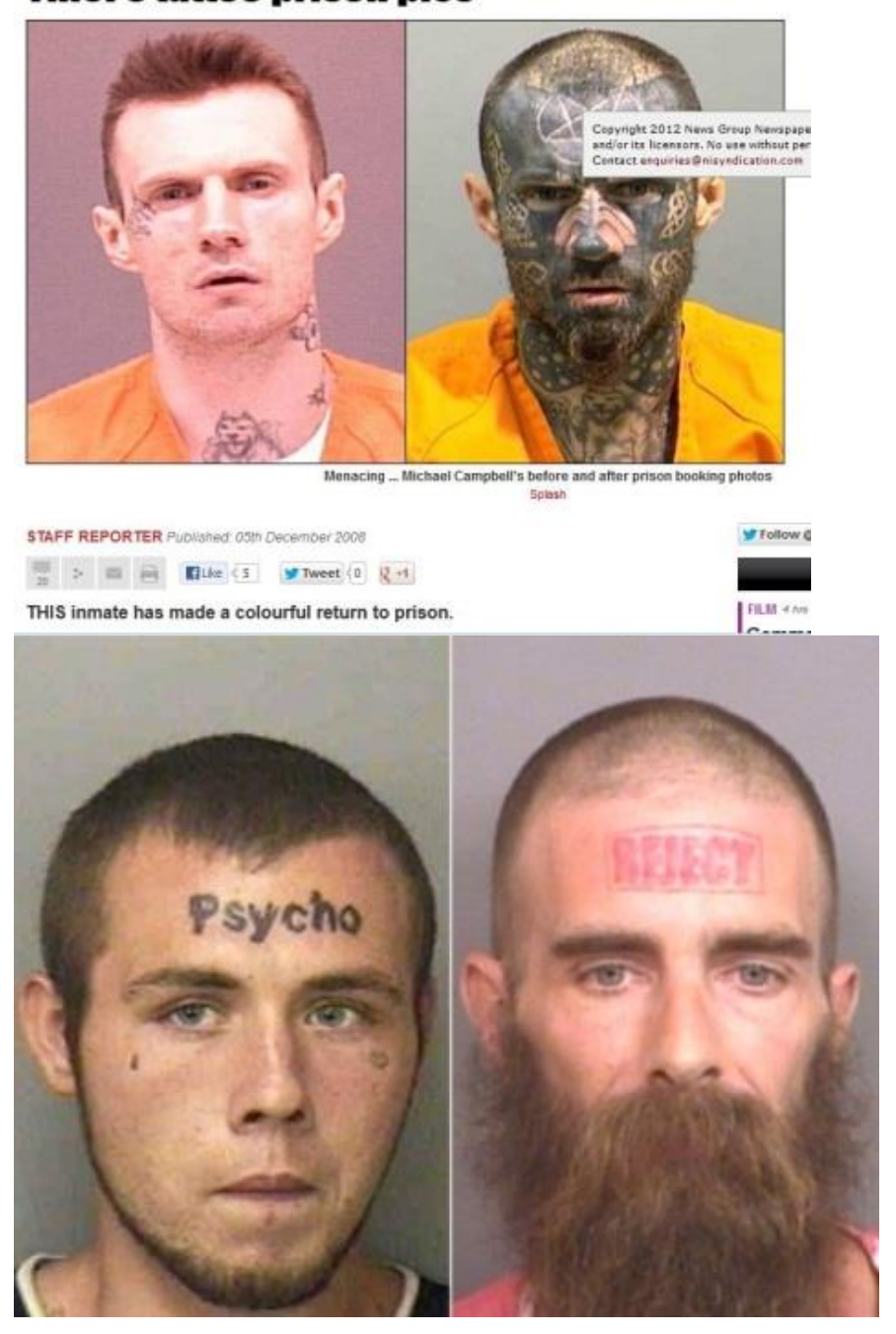

Even more disturbing is the tabloid fascination for 'monsters' and 'freaks'. It is reminiscent of late American photographer Diane Arbus' controversial portraits but without the sense of art that might enquire into the wider meaning. We are now regaled by the inmates of Federal and State prisons who have tattooed their faces. Had strange haircuts or are cleared in a state of extreme drink or drug abuse. The UK tabloids freely use US mugshots (being more readily available and more outlandish than their UK equivalents) as a free freak show. They are there to jeer at the spectacle.

Our voyeuristic interests are most clearly demonstrated by the categories set out by the US websites that specialise in mugshots. Smoking Gun has:

$\underline{\text { Bad Attitude }}$ 
$\underline{\text { Classics }}$

$\underline{\text { Cleavage }}$

$\underline{\text { College }}$

$\underline{\text { Fogeys }}$

Funny Faces

$\underline{\text { Grills }}$

$\underline{\text { Hair }}$

$\underline{\text { Hawaiian Shirts }}$

$\underline{\text { Message T-Shirts }}$

$\underline{\text { Nascar }}$

Obama

$\underline{\text { Ouch }}$

$\underline{\text { Pacino }}$

Pretty Perps

$\underline{\text { Strippers }}$

Tattoos

$\underline{\text { Topless Men }}$

Topless Women

$\underline{\text { Tramp Stamps }}$

$\underline{\text { Uniforms }}$

$\underline{\text { Unusual Suspects }}$

$\underline{\text { Weepy }}$

$\underline{\text { Well Dressed }}$

It has a special category for celebrity which is subdivided.

$\underline{\text { B-List }}$

Business

Page | 27 


\section{Gangsters}

\section{Historical}

$\underline{\text { Hollywood }}$

$\underline{\text { Killers }}$

$\underline{\text { Music }}$

$\underline{\text { Nuisances }}$

$\underline{\text { Politics }}$

$\underline{\text { Sports }}$

$\underline{\text { Television }}$

Carney says that today we know that a mugshot is not merely an instrument of identification." It also involves the capture of a suspect, the enactment of power of arrest and, in its release to the mass media, not only an indication of policing power in general but also, Moreau-Christophe might have hoped, its capacity to brand a detained body with shame." (Carney 2010, 23)

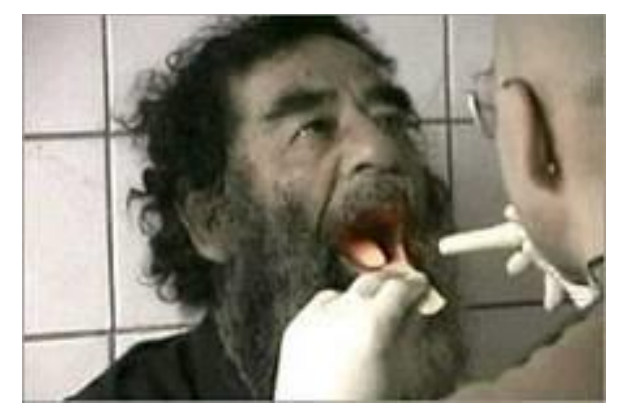

This photograph of Saddam Hussein taken after capture while having a DNA swab taken is not a good photograph in a representational sense, it is in the spirit of the mugshot and was widely published. I would suggest because it shows humiliation of the once mighty dictator and the power of those who captured him.

This essay started with a picture of Robert Murat. The British tabloid coverage of the Maddy McCann case was widely seen a nadir in British popular journalism for its intrusion, facile speculation and inaccuracy, driven by neo-liberal pressures to boost circulations. (Only to be surpassed later by the phone hacking and the bribery of public servants scandal) Murat was cleared as a suspect. Murat sued eleven British newspapers including the Sun for their coverage of his period as a suspect. In July 2008 it was announced that he would be paid damages of $£ 500,000$ and this was reported by The Sun illustrated by a head and shoulders photograph. Murat is smiling, looking 45 degrees to the camera and has sky in the background therefore the visual grammar clearly says this portrait is not a mugshot. In August 2008 the Portuguese police released the Murat file. This is where the mugshot of Murat comes from. Murat was no longer a suspect so the mugshot has no relevance. The Sun 
claimed they published it to record its existence. I think it fair to suspect the Sun editorial team understood, explicitly or implicitly, the semiotic levels of meaning attached to a mugshot. Having recently made a payment of damages to Murat they could not resist the temptation to further humiliate him by showing his arrest photograph. They full well knew that this would further denigrate Murat in the eyes of their readers. The storyline pretends there to be a story but an experienced reporter knows there is not. The story is not in the image but in its connotations.

\section{Conclusion}

The mugshot retains its role as a method of recording the images of those arrested and even as a means of identifying those who have committed crimes. The state clearly wants mugshots to have a salutary effect but the images themselves have become part of a festival of crime. Picking up on the ideas proposed by cultural criminology, partial as they may actually be, that crime is a cultural construct we might ask what mugshots are missing from the modern 'rogue's gallery'. One obvious answer might be bankers responsible by their negligence for the greatest economic crisis since the great depression. Our cultural and political structures deliberately do not allow wholesale action against this class of criminal, despite compelling evidence of crime, because it is deemed not in the interests of the state

Mugshots retain their role in the news media to provide portraits in crime stories but as we have seen they are also increasingly used in disturbing ways. Hall says that the structure of 'news values' appear as a neutral, operational level in news production naturally connecting stories and events with persons, attaching qualities, status, positions in the social world to anonymous events. News values search out the 'drama', the 'human interest', behind impersonal historical forces. "Yet, these operational values are not, in the end, neutral values. As Althusser has argued, it is precisely by operating with 'the category of the subject', and by producing in the reader 'familiar recognition', that a discourse becomes ideological." (Hall,1973, 180. In late modernity the part of the media that most use mugshots - the tabloid press and increasingly tabloid TV - is part of a process that separates rather than brings society together. There is the schadenfreude, the thrill, the derision and the fear when the suspect is pictured. What part does tabloid culture play in shrugging off centuries of penal reform and seek to create a modern version of the medieval spectacle of public punishment? We are encouraged to laugh at the freaks, monsters and defrocked celebrities. We are not encouraged to respond to these people as manifestly apparently deeply disturbed human beings. 'The photograph becomes both the scene and means of photographic punishment,' Phil Carney says: 'There is something transcultural rather than intercultural about the photograph as a material force and it is in this way that we might consider a photographic force that has effects in terrorism, war and punishment, all of which may be regarded as connected through the image. Here is where we will encounter the punitive gaze, where forces in performance are better understood in terms of Artaud's 'Theatre of Cruelty' rather than representation, knowledge, cognition or meaning." (Carney 2005)

In late modernity, a time which has coincided with media excess, the tabloid press, though not exclusively, have been the prime perpetrators. That the overwhelming desire of neo- 
liberalism is to situate as 'other' those who do not sit comfortably in our 'beleaguered' cultural group is as worrying and reminiscent of how positivism fed fascism. Carney has made the point: "As a toxic miasma of war, security and risk management envelopes our politics, a kind of fascism or microfascism flows through the late-modern theatres of cruelty scattered across the glittering never lands of consumerism." What more, it is hardly recognised. As Foucault (1988) suggests, we judge the criminal not the crime, and for all our postmodern sophistication, the beginning of the $21^{\text {st }}$ Century finds us still falling back on the positivist discourses of $19^{\text {th }}$ century criminology, forgetting what disastrous consequences those radical thoughts had for humanity in the $20^{\text {th }}$ century. Mugshots may be a simple form but they can tell us a lot about the way photographs help us justify alienation and lack of empathy. And if we think we have progressed since 1870 and, for instance, we no longer take mugshots of children then perhaps this is a useful reminder. These images were controversially published in 2001 by a number of media organisations and reported to the Attorney-General for doing so.

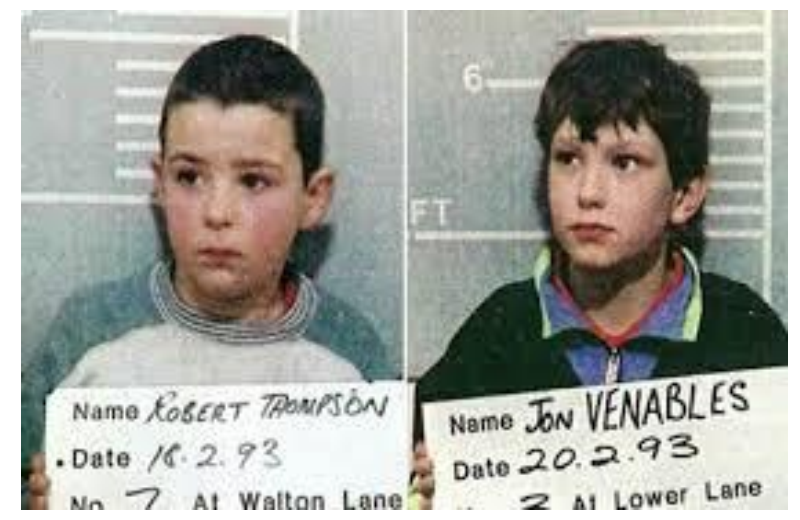

We seek to distance ourselves from 'feral' children, 'monster' women, 'criminal' ethnic groupings, the inadequate, to exclude them from our society in the hope they are different, but therein may lie problem, perhaps they are not different and we are them.

Reference

Barthes, R 1993 [1981 \} Camera Lucida, Vintage Classics Series, New York Random House

Bate, D (2007) 'The Archaeology of Photography: Rereading Michel Foucault and the Archaeology of Knowledge'. Afterimage. vol.35 no.3 (Sept-Oct 2007)

Benjamin, W (1999) A Little history of photography" in Walter Benjamin: Selected Writings, Volume 2, 1927-1934. Boston: Belknap Press

Benjamin, W [1936] The Work of Art in the Age of Its Technological Reproducibility, and Other Writings on Media, Harvard University Press,

Carney, P. (2005)“The Punitive Gaze” conference session note. Accessed 22 Apr 2013 at: www.sietar-europa.org/congress2005/in.../W33.doc

Carney, P. "Crime, punishment and the forces of photographic spectacle" in Hayward, Keith J and Pressdee, Mike (2010) Framing Crime. Abingdon: Glasshouse-Routledge. 
Debord (1977) [1967] The Society of the Spectacle, translation by Fredy Perlman and Jon Supak (Black \& Red, 1970; rev. ed. 1977). Online at Library.nothingness.org

Dukes, M (forthcoming 2013) Caught on Camera: Five Dorset Prisoners in Victorian England in Lashmar, P (ed) Proceedings of Dorset Natural History and Archaeological Society. Dorchester Vol 134.

Ferrell, J (1998) 'Criminological Verstehen', in J Ferrell and M Hamm (eds) Ethnography on the Edge. Boston: Northeastern University Press

Foucault, M. (1977) Discipline and Punish. London Penguin 1977

Frizot, M. (ed) (1998) A New History of Photography. Konemann

Gilardi, A. (2003) Wanted. Milan, Bruno Mondadaori

Hall, S. (1973) 'The determination of news photographs' in Cohen, S and Young, J. The Manufacture of News: A Reader. London: Sage

Hall, Stuart., Critcher, Charles., Jefferson, Tony., Robert, Brian and Clarke, John. (1978) Policing the Crisis, Mugging, the State and Law and Order, London: Palgrave Macmillan

Hayward, K, and Young, J. Introduction to Cultural Criminology: Some Notes from the $\underline{\text { Script }}$

Hight, E M, and Sampson, G D. (2002) Colonialist Photography. London: Routledge. Lacan, E. (1857)_Esquisses Photographiques [Photographic Sketches].

Lombroso, C. (1995) Delitto, genio, folio, Scritti scelti. Turin: Bollati Boringhieri Maxwell, A. (1999) Colonial Photography \& Exhibitions. London: Leicester University Press.

Mayr, A. and Machin, D. (2012) The Language of Crime and Deviance. London: Continuum Mirzoeff, N. (2013) Visual Culture Reader. 3rd ed. Abingdon: Routledge.

Papi, G. (2006) Booked. Translated by Jamie Richard. New York: Seven Stories Press

Schopenhaeur, A. (2000) Pareerga and Paralipomen: Short Philosophical Essays. Translated by J.Payne. New York: Oxford University poress.

Sontag, S. (1990) On Photography. New York: Anchor Books

Smith, S M. (2000) 'Looking at One's Self through the eyes of others': W E B Du Bois's photographs for the 1900 Paris Exposition. African American Review, Vol 34. No 4 (Winter 2000). pp 581-599 
Syson, N (2011) Shop an Edwardian Moron. The Sun. 18 Aug 2011, Accessed 13 April 13 at http://www.thesun.co.uk/sol/homepage/news/3758824/Edwardian-version-of-The-SunsShop-A-Moron-rogues-gallery.html

Tagg, J (1988) The Burden of Representation. London: Palgrave Macmillan.

\section{Secondary References}

Bertillon, A (1980) La Photographie judiciare avec un appendice sur la classification et l'indentification antropomettrique. Paraigi: Guathier-Villars.

Bignell, J (1997): Media Semiotics: An introduction. Manchester: Manchester University Press.

Domke, D., Perlmutter, D and Spratt, M (2002) “The Prime of our times? : An examination of the 'power' of visual images. Journalism 2002 3: 131-159

Finn, J. M. (2009). Capturing the criminal image: From mug shot to surveillance society

Eccles, A (2012) 'Pretending to be seafaring men' in Lashmar, P (ed) Proceedings of Dorset Natural History and Archaeological Society. Dorchester Vol 133.

Geertz, C (1973) The Interpretation of Cultures. New York: Basic Books

Jäger, J. (2001) Photography: a means of surveillance ? Judicial photography, 1850 to 1900 in Crime, History \& Societies. Vol 5 no 1 p. 27-51

Jermyn, D. (2003) 'Photo stories and family albums: imaging criminals and victioms on Crimnewatch UK' in Mason, P.(ed) Criminal Visions. Collumpton: Willan.

Machin, D and Mayr, Andrea (2012) How to do: Critical Discourse Analysis. London: Sage

\footnotetext{
${ }^{\mathrm{i}}$ http://www.dailymail.co.uk/news/article-2159085/Fascinating-records-67-000-19th-century-criminalspublished-online-time.html

ii 'Maddy' McCann a young English girl mysterious disappeared in 2007, as her parents having dinner a short distance away while on holiday in Portugal. It became a tabloid cause celebre and a by-word for newspaper excess.

iii The photograph appeared in the Sun newspaper in August 2008 and remains on their website.

${ }^{\text {iv }}$ Silcott was later jailed for another serious offence.

${ }^{v}$ I'd like to thank my colleague Benjamin Zephaniah for reminding me and giving details of the use of this image.

${ }^{\text {vi }}$ http://news.bbc.co.uk/1/hi/uk/3208724.stm

${ }^{\text {vii }}$ UCL are currently working on a project to digitise the papers of Francis Galton

viii Anthropologist Doctor Joseph Mengele performed medical experiments on inmates at Auschwitz

${ }^{\text {ix }}$ Understanding Media (from Framing)
} 